\title{
MINERALOGIA DE SOLOS DE UMA TOPOSSEQUÊNCIA
}

\section{DE ATIBAIA, S P}

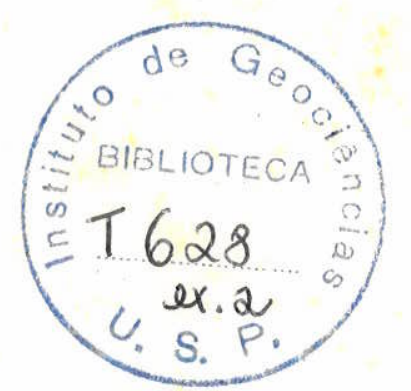

Orientador

Prof. Dr. Umberto G. Cordani
Dissertação de Mestrado apresentada ao Instituto de Geociências da Universidade de São Paulo.

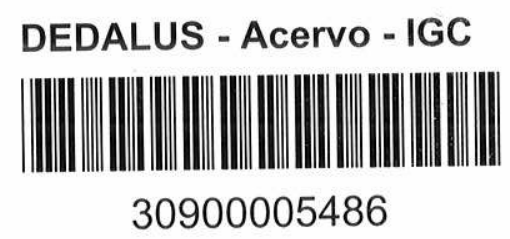

SÃO PAULO

1975 
A Suely, Viviane e Renato ofereco 
INDICE

1 - INTRODUÇAO

2 - REVISAO BIBLIOGRAFICA 3

2.1 - CONCEITO DE TOPOSSEQUENCIA 3

2.2 - MINERALOGIA DA FRAÇÃO AREIA 8

3 - CARACTERISTICAS DO MEIO FISICO 11

3.1 - LOCALIZAÇÃO DA ÂREA 11

3.2 - RELEVO 11

3.3 - GEOLOGIA GERAL 12

4 - MATERIAL E METODO 17

$\begin{array}{ll}4.1 \text { - SOLOS } & 17\end{array}$

4.2 - MËTODOS 24

4.2.1 - PRE TRATAMENTO E SEPARAÇOEES PARA AS ANÁLISES DAS AMOSTRAS 24

4.2.2 - ANALISE QUANTITATIVA DOS MINERAIS DA FRAÇAOO ARGILA 29

4.2.3 - ANALISE QUANTITATIVA DOS MINERAIS DA FRAÇÃO AREIA. 40

4.2.4 - MEDIA DE INTEMPERISMO COM BASE NA FRAÇÃO ARGILA 40

4.2.5 - MEDIA DE INTEMPERISMO COM BASE NA FRAÇÃO AREIA 42 
5 - RESULTADOS E DISCUSSÃO

6 - CONCLUSÕES

75

7 - RESUMO

78

8 - BIBLIOGRAFIA

80

9 - AGRADECIMENTOS

87 
Figura 1 - Localização do município de Atibaia

Figura 2 - Carta de solos do município de Atibaia, estando assinalada a linha $A-B$ que corta os solos da topossequēncia estudada

Figura 3 - Secção esquemātica mostrando a distribuição no relevo e a sequência das uni dades de solos

Figura 4 - Carta das formações superficiais do mu nicípio de Atibaia

Figura 5 - Fluxograma das anālises mineralōgicas

Figura 6 - Curva de calibração para caulinita por anālise tērmica diferencial

Figura 7 - Curva de calibração para gibbsita por anälise tërmica diferencial

Figura 8 - Difratogramas da fração argila de amos tras orientadas da unidade Itapetinga, perfil 1011

Figura 9 - Difratogramas da fração argila de amos tras orientadas da unidade Rio Acima, perfil 1037

Figura 10 - Difratogramas da fração argila de amos tras orientadas da unidade Samambaia, perfil 1032

Figura 11 - Termogramas da fração argila da unidade Itapetinga

Figura 12 - Termogramas da fração argila da unidade Rio Acima 
Figura 13 - Termogramas da fração argila da unidade Samambaia

Figura 14 - Difratogramas da fração argila de amos tras orientadas da unidade Rosārio,per fi 1055

Figura 15 - Difratogramas da fração argila de amos tras orientadas da unidade Cachoeira, perfil 1034

Figura 16 - Difratogramas da fração argila de amos tras orientadas da unidade Cachoeira, perfil 1054

Figura 17 - Difratogramas da fração argila de amos tras orientadas da unidade Caetetuba, perfil 1064

Figura 18 - Difratogramas da fração argila de amos tras orientadas da unidade Caetetuba, perfi 1052

Figura 19 - Termogramas da fração argila da unidade Rosārio, perfil 1055

Figura 20 - Termogramas da fração argila da unidade Cachoeira, perfil 1034

Figura 21 - Termogramas da fração argila da unidade Cachoeira, perfil 1054

Figura 22 - Termogramas da fração argila da unidade Caetetuba, perfil 1064

Figura 23 - Termogramas da fração argila da unidade Caetetuba, perfil 1052

Figura 24 - Difratogramas da fração argila de amos tras orientadas da unidade Piqueri,per fil 1051 
Figura 25 - Difratogramas da fração argila de amos tras orientadas da unidade piqueri,per fil 1031

Figura 26 - Difratogramas da fração argila de amos tras orientadas da unidade Tanque, per fi 11063

Figura 27 - Termogramas da fração argila da unidade Piqueri, perfil 1051

Figura 28 - Termogramas da fração argila da unidade Piqueri, perfil 1031

Figura 29 - Termogramas da fração argila da unidade Tanque

\section{LEGENDA DOS QUADROS}

Quadro 1 - Composição mineralōgica da fração argila e cālculo médio do perfil do intemperismo médio (IM) segundo JACKSON \& SHERMAN(1953) de alguns perfis de solos do município de Atibaia, SP

Ouadro 2 - Teores de material amorfo do solo livre de matēria orgānica determinados pelo teste rāpido de FIELDS \& PERROTT, 1966

Quadro 3 - Composição mineralögica da fração areia(0,1 $-0,05 \mathrm{~mm})$ e razão de intemperismo dos minerais leves (RIL) segundo RUHE(1956) de alguns perfis de solos do município de Atibaia, SP 
0 estudo em topossequências reveste-se de grande importância pelas informações que dâ para relacionar a associação de diferentes unidades de solos dentro da paisagem.

Quando associado a estudos de Geologia, Geomorfologia e Mineralogia, o estudo de topossequências, permite verificar o grau de intemperismo relativo entre solos desenvolvidos em partes altas e baixas. Per mite também, evidenciar tendências de formação de mine rais secundärios, dependendo da posição do solo na topografia, do clima, do material de origem e outros fatores.

A maioria dos estudos de topossequências tem sido realizados em solos de rochas ígneas bâsicas e se dimentares. 
O objetivo deste trabalho foi o de realizar um estudo de topossequência em uma região de predominância de solos desenvolvidos de rochas äcidas, provenientes principalmente de granitos, gnaisses e em escala menor granitos/gnaisses, micaxisto e sedimentos modernos (CARVALHO \& ROTTA, 1974). Este estudo, que complementa o le vantamento pedológico do município de Atibaia, em nível de ordem de solos (CARVALHO et a1., 1972), dä ênfase a estudos mineralógicos da fração argila e classificação dos solos ao nível de família por critērios modernos (EUA, 1970). 
Com a presente revisão bibliográfica pretendeu-se efetuar um levantamento dos principais trabalhos realizados em topossequências de solos com base nos dados mineralógicos das frações argila e areia.

\section{1 - CONCEITOS DE TOPOSSEQUENANIA}

MILNE citado por RUHE (1960) define catena como uma sequência de solos encontrada entre o topo de morros baixos e a baixada, sequência essa desenvolvida de acordo com as condições de drenagem e com a história passada da superfície, onde os solos se desenvolvem atualmente.

MILNE considera ainda que podem ser distinguidas duas variações: em uma delas a topografia é modelada por denudação ou outros processos em uma formação 
originalmente similar quanto ao caräter litolögico. Assim, solos diferentes são consequências de condições de drenagem, diferente transporte do material erodido e $1 \underline{i}$ xiviação, translocação e redeposição dos constituintes químicos móveis. Na outra variação, a topografia foi en talhada em duas ou mais formações supostas litologicamen te diferentes. A uniformidade do material de origem foi tido por MILNE de interesse secundärio. Ao mesmo tempo excluiu de catena padrões de solos repetitivos, subordi nados a afloramentos rochosos mas não relacionados com diferenças de niveis.

Discute-se bastante, WATSON (1965), se os solos componentes de uma catena precisam estar associados geo graficamente em uma sequência contínua. MILNE usou o conceito de catena como uma unidade de mapeamento, consequentemente os solos se cncontravam fisicamente juntos. Entretanto, BUSHNELL (1942) redifiniu o termo cate na para incluir solos de todas as situações hidrolögicas possiveis de um dado material de origem, sob um cli ma uniforme estando ou não os solos associados juntos em uma sequência contínua. Verificou ainda que em âreas com grande uniformidade topogräfica e semelhança na dre nagem, o conceito de catena de MILNE é difícil de ser aplicado. BUSHNELL (1942) considera portanto que o termo catena deva ser usado para a sequencia de solos sobre um mesmo material de origem.

INATSON (1965) considera ainda que as duas defi 
nições de catena tem diferentes aplicações e ambas são largamente usadas. Atualmente, catena é apenas um de um nümero de associações topogräficas de solo para uso de classificação e mapeamento.

RUHE (1960) propõe as seguintes denominações para os elementos da catena de MILNE: terras a1tas (up1 and), pedimento de encosta (pediment backshope), pedimento de sopé (pediment footslope) e aluvião (alluvial toeslope). Considera ainda que ocorre um maior desenvol vimento dos solos em direção a região do aluvião. FRAN MEYER et a1., (1969), estudando os efeitos que o aspecto e a posição da encosta exercem nas propriedades do solo, incluindo a temperatura do solo, chegaram as seguintes conclusões: os solos em posição intermediäria da encosta, apresentam maior quantidade de material gros seiro do que nas partes superiores ou inferiores; os si tuados nas partes baixas são mais frios e com maior saturação de bases, teor de argila mais elevado com predo minância da caulinita.

BIDWELL \& PAGE (1950) em seus estudos das arg $\underline{i}$ las da catena de Miami em Ohio, concluiram que as diferenças de drenagem tiveram pouco efeito nos tipos de argila encontrado, Do mesmo modo MARTIN \& RUSSEL (1952) estudando solos de Nova York concluiram que as argilas contidas naquela catena não foram suficientemente intem perizadas para alterar o folhelho original.

Diferenças em condições hidrológicas sob clima 
uniforme geralmente são associadas a diferenças no relevo e na morfologia do solo. TEDROW (1951) separou solos em regiões de escarpas de solos com morfologia idêntica de äreas mais baixas devido a diferenças de umidade e po tencial agrícola.

GREENE (1947) realça o valor da catena MILNE no estudo da formação do solo em virtude desse conceito implicar na drenagem da água morro abaixo.

A sugestão apresentada por autores como BUSHNELL (1942) no sentido de limitar o conceito de catena a uma sequência de solos derivados de um mesmo material de origem foi combatida por GRIFFTH (1952).

A catena definida por BUSHNELL (1942) não tem valor para a classificação e mapeamento de solos em regiões onde a drenagem varia mais que o material de origem. Tais condições são encontradas, por exemplo, na Escócia e Canadá, WATSON (1965).

JOHNSON \& JEFFRIES (1957), estudaram o efeito da drenagem no intemperismo dos minerais de argila na cate na de Allenwood, Pensilvânia e verificaram que a mineralogia da fração argila era semelhante em todos os solos, porém a variação se dava na taxa de intemperismo.Constataram ainda que esta variação era devida a drenagem.

MONIZ \& CARVALHO (1973) apresentam tentativamente uma correlação dos solos formados a partir do arenito 
Bauru na região Noroeste do Estado de São Paulo com os elementos da catena de MILNE e com denominações propostas por RUHE (1960). Assim o solo Podzolizado variação Marília estaria relacionado à região correspondente às "terras altas" do diagrama de RUIE e seria formado sobre - arenito Bauru praticamente sem recobrimento. Essa rela ção seria corroborada pelo menor grau de intemperismo do podzolizado variação Marília cuja relação com as outras unidades taxonômicas é a seguinte: Podzolizado variação Marília<Podzolizado variação Lins<Latossolo Vermelho Escuro fase arenosa. O Podzolizado variação Marília corres ponderia ao pedimento de encosta e o Latossolo ocuparia a posição equivalente ao pedimento de sopé. Esse material se apresenta num estāgio mais avançado de intemperismo, o que explicaria os teores relativamente elevado de caulinita $(80 \%$ a $90 \%)$ na fração argila.

ANDRADE et a1.. (1974), estudaram a relação genética existente entre solos, com boa e mä drenagem, de três catenas de solos, através da anảlise mineralógica da fra ção argila. Tal análise revelou que nos solos formados em condi ções de drenagem pobre, o teor de gibbsita ê inferior, ou mesmo pode ser nulo, em relação ao solo da mesma catena, formado em con dições de boa drenagem. Verificaram tambëm, o aparecimen to de montmorilonita ou um ligeiro aumento do seu teor nos solos formados sob condições de má drenagem. A cauli nita foi o argilomineral dominante em todos os perfis que estudaram. Encontraram uma 1igeira diminuição no teor de caulinita em superfície havendo em compensação um aumento no teor de gibbsita o que está de acordo, se- 
gundo esses autores, com a sequência normal de intemperismo proposta por JACKSON et a1., (1948).

ANDRADE et a1., (1974), observam, ainda, que a brusca diminuição do teor de caulinita em superfície não se deve a pedogênese mas sim uma descontinuidade 1itoló gica.

LEPSCH (1973), efetuou a caracterização de qua tro perfis de uma topossequência na região de Rio Claro, SP, com os objetivos de descrever e comparar os quatro perfis. Um dos perfis está localizado na parte superior da encosta, um na inferior e os outros dois em posição de meia encosta. Conclui, que há um decréscimo de inten sidade de intemperismo do membro superior ao inferior da topossequência.

\section{2 - MINERALOGIA DA FRAÇÃO AREIA}

A finalidade do estudo mineralógico da fração areia dos solos é contribuir para o conhecimento de sua gênese e classificação onde se procura filiar os solos às rochas existentes como também avaliar a reserva potencial dos nutrientes do solo de certa importância no que diz respeito à fertilidade. O estudo mineralógico da fração areia permite também o cálculo da razão de in temperismo como ainda a avaliação do grau de alteração dos solos.

HASEMAN \& MARSHALL (1945), estudando os mine- 
rais pesados julgam de grande importância o reconhecimen to da rocha matriz e a avaliação das mudanças que ela po de sofrer durante a formação do solo. Usam o zircão e turmalina como indicadores imóveis.

Concluem que a origem de um solo é refletida na espécie e quantidade de minerais pesados presentes. A de terminação qualitativa e semiquantitativa dos pesados po de, em casos favoräveis, evidenciar a origem de um solo em se comparando com o material de origem; esses estudos tambêm pödem mostrar rapidamente os fenômenos de descontinuidade do material de origem do solo a diferentes pro fundidades; hornblenda, devido a sua grande distribuição e resistência moderada ao intemperismo é um bom mineral para ser usado na comparação da severidade do intemperis mo dos diferentes horizontes de um solo e de solos forma dos sob condições climāticas diferentes.

PORTAS \& FURTADO (1964); estudaram as frações areia e argila de oito perfis de solos desenvolvidos sobre granitos, na região de Angola, com o objetivo de separar e analisar os minerais da areia para estudar as condições de formação bem como as relações com a atual fase de evolução dos respectivos solos e fazem uma revisão crítica dos métodos utilizados na mineralogia das areias. Procuraram exprimir quantitativamente a evolução de um perfil de solo baseados em minerais indices, is to ê, minerais não migrảveis e não meteorizāveis, usando pa ra tal a fração areia fina por ser constituída predominantemente de quartzo e sem eluviação. 
GIRARDI \& MELFI (1963), estudaram a composição mineralógica dos solos da Série Taquaral na Estação Experimental de Campinas, solos esses provenientes de diabäsio e sedimentos glaciais. Nesse trabalho constataram a presença de minerais de contribuição de sedimentos glaciais em todos os horizontes atë grandes profundidades (horizonte C) e a existência de gibbsita na fração areia grossa pseudomórfica sobre feldspatos. Dentre outras con clusões notaram que o estudo morfológico de anatảsio e epídoto não permitiu conclusões a respeito de sua origem: se autoctone ou proveniente de sedimentos glaciais. Outra conclusão é que a presença de zircão, monazita, turmalina, sillimanita (além de quartzo e opacos arredondados) evidenciam a contribuição dos sedimentos glaciais para a formação da Série Taquaral. A existência de gibbsita pseudomörfica sobre feldspato sugere transformação direta deste em gibbsita.

A presença de zircão, monazita,sillimanita, tur malina, rutilo, granada, estaurolita e cianita mostram a grande contribuição de sedimentos de origem glacial da Série Taquara1 pelos estudos efetuados por MELFI et a1., (1966). Concluem que a relação verificada entre os resíduos leves e pesados é fator decisivo na diferenciação entre solos derivados de diabásio e provenientes de rochas sedimentares glaciais. Concluem também que a existência de feldspatos nos perfis, vem mostrar que tais so los possuem ainda reservas potenciais em elementos nutri entes e que vão sendo gradativamente liberados pelos processos de intemperismo. 


\section{3 - CARACTERISTICAS DO MEIO FISICO}

\section{1 - LOCALIZAÇÃO DA ÃREA}

o município de Atibaia (em que se acha a topos sequência estudada), localiza-se na região fisiogrâfica do Estado de São Paulo descrita por MONBEIG (1954) como Planalto Atlântico, subregião da Mantiqueira, entre os paralelos $46^{\circ} 25^{\circ}$ e $46^{\circ} 45^{\prime} \mathrm{S}$ e os meridianos $23^{\circ} 0^{\prime}$ e $23^{\circ} 15^{\circ}$ WG (Figura 1). Dista cerca de $60 \mathrm{~km}$ ao norte da capital do estado e ocupa uma ärea de $478 \mathrm{~km}^{2}$.

\section{2 - RELEVO}

Atibaia apresenta um relevo caracterizado por um peneplano bastante dissecado com altitudes entre 800 $m$ e $1400 \mathrm{~m}$, tratando-se, segundo DEFONTAINES (1935) e DE MARTONE (1943), de um relevo apalachiano retrabalhado por novos ciclos de erosão. 
O município está situado numa região serrana com altitudes que chegam a alcançar $1390 \mathrm{~m}$, como o pico da Pedra Grande,e com declives em geral superiores a $60 \%$.

Constam ainda do relevo, colinas mamelonares com altitudes em torno de $1000 \mathrm{~m}$, constituindo talvez parte das "superfícies das cristas médias" descritas por DE MAR TONE (1943). Ocorrem também colinas mais baixas com altitudes que raramente ultrapassam $800 \mathrm{~m}$ e que talvez se tra te da "superfície neogênica" conforme denominação de DE MARTONE (1943).

\section{3 - GEOLOGIA GERAL}

As rochas do município de Atibaia pertencem ao complexo brasileiro ocorrendo também granitos e granitos gnaíssificados anteriores ao Grupo São Roque.

Os inümeros trabalhos geológicos realizados neste grupo restringem-se principalmente à região sul do Estado, onde a maior concentração de recursos metālicos e de calcários estimularam estudos geológicos mais detalhados ficando de certa forma mal conhecida a parte leste do Estado, inclusive o município de Atibaia.

Tais rochas fazem parte de uma unidade geocrono 1ógica e geotectônica ampla do chamado cinturão orogenéti co Ribeira e que se estende desde a Bahia até o Uruguai ao longo da costa oriental da América do Sul, dentro do Ciclo Brasiliano $(550 \pm 100 \mathrm{~m} \cdot \mathrm{a}$.$) .$ 


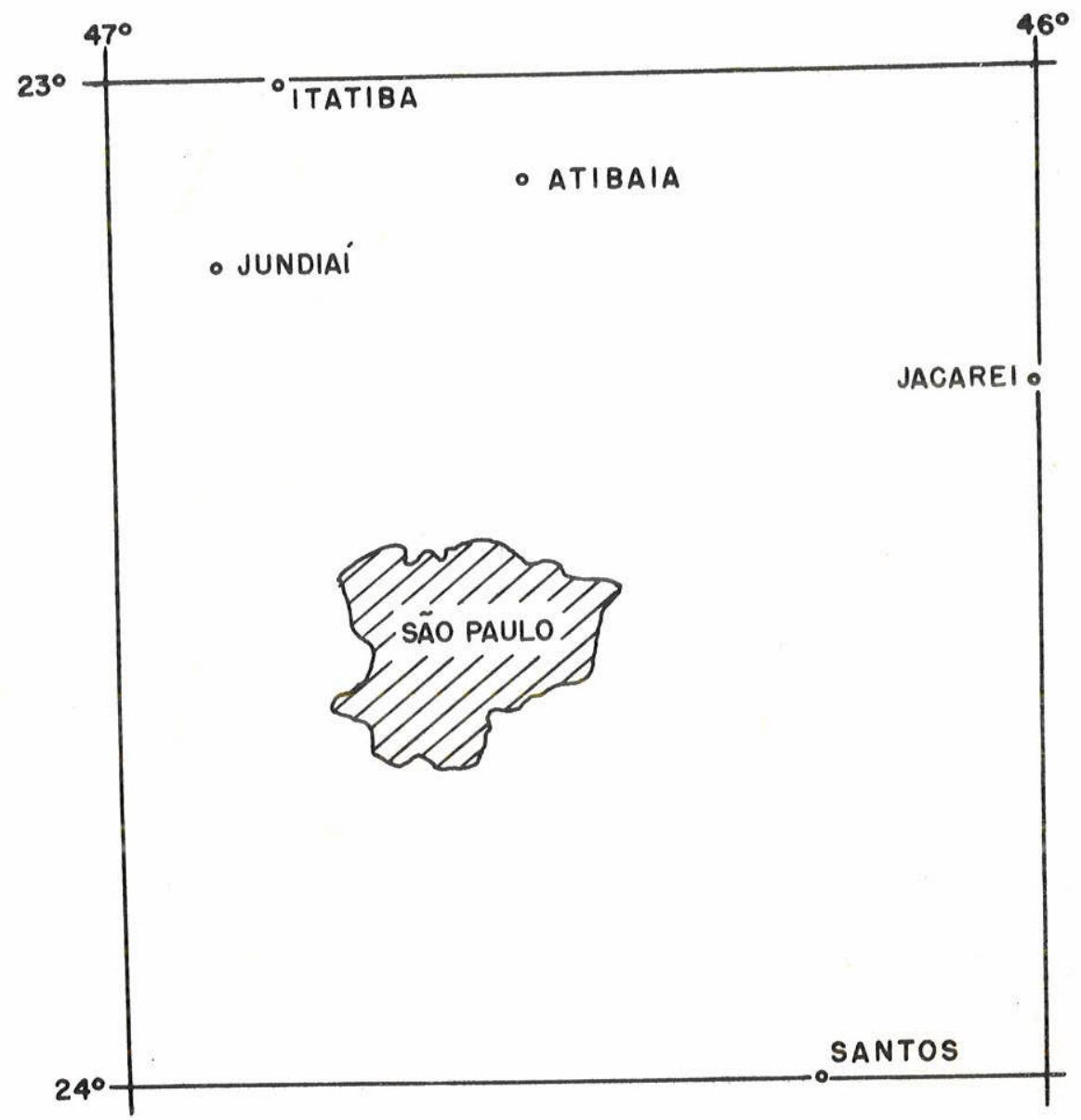

Figura 1 - Localização do município de Atibaia 
Existem na realidade mais de uma centena de tra balhos relacionados ao Grupo Açungui-São Roque, porém a área de Atibaia não mereceu ainda qualquer estudo detathado.

0 vale do rio Atibaia constitui-se desde sua ca beceira até o sítio urbano de Campinas, por rochas do complexo metamórfico ou "migmatito indiferenciado" CORDANI \& BITTENCOURT (1967) e diz respeito às rochas de grau de metamorfismo mais elevado do provável cinturão do Ribeira.

São gnaisses e migmatitos de diversas naturezas com intercalações de quartzitos e micaxistos. Metassedimentos de caráter epizonal, constituídos de filitos e mi caxistos além de faixa relativamente extensa de quartzitos foram constatadas em perfis de reconhecimento transversais ao rio Atibainha, BITTENCOURT (1972).

Corpos graniticos em algumas ocorrências expres sivas, acham-se associados ao complexo.

Existem também ocorrências de pequenas manchas de rochas sedimentares com espessura máxima de 10 metros, provavelmente de idade pliocênica, PENALVA (1971), sendo que as regiões de relevo colinoso acham-se recober tas por sedimentos mais modernos.

ALMEIDA (1964) descreve a região como uma zona situada na faixa de rochas precambrianas em que predomi- 
nam rochas gnaissicas com intercalações de micaxistos e ainda granitos e granitos gnaissificados de idade pré São Roque, que são mais deformadas que as posteriores.

Durante o mapeamento geológico das formações su perficiais efetuado no município, CARVALHO \& ROTTA(1974), notou-se certa orientação ou xistosidade dos constituintes mineralógicos como também fraturamento e milonitização. Algumas dessas eruptivas ácidas apresentavam-se de tal forma gnaissificadas que suas distinções se tornara extremamente difícil.

A direção predominante dos dobramentos è NE-SW e localmente N-S, WOHLERS et a1., (1954). Para estes autores os granitos são consequência de granitização dos gnaisses, não tendo ligação entre os corpos; quanto aos gnaisses, são fortemente fitados e ricos em biotita confundindo com micaxistos quando aqueles estão decompostos devido ao intenso metamorfismo geral. Apontam também ocorrências de äreas ricas em anfibólio como tambẻm aflo ramentos de quartzitos.

$\Lambda$ descrição petrogräfica macroscónica de alguns dos principais grupos de rochas encontrados no município de Atibaia é a seguinte:

Metamōrficas

Biotita-gnaisse, leucocrātico a mesocrático,gra nulação média a fina, fraca gnaissificação. Alguns con- 
têm granada. Gnaisse porfiróide, mesocrātico granulação média com porfiroblastos de feldspato; xistosidade boa, rico em biotita. Quartzito, leucocrático de granulação grossa ( 5 a $8 \mathrm{~mm}$ ) e fina; uniminerālico (quartzo); xisto sidade ausente. Muscovita-xisto, leucocrätico, macrogra nular; xistosidade e divisibilidade boas.

\section{Magmáticas}

Ocorrem granitos de granulação média a fina como também profirítico, alguns ricos em biotita. Outro ti po é o granito gnaisse que apresenta bastante máficos e é ligeiramente orientado.

\section{Sedimentares}

Em sedimentos de pequena extensão e de idade provavelmente neocenozóica encontrou-se a seguinte sequência: Conglomerado - seixos centimétricos predominantes, cimento argiloso; textura clästica com seixos mal arredondados, predominantemente de quartzito. Arenito conglomerätico - grãos predominantemente de 0,5 a $1,0 \mathrm{~mm}$, textura clástica com grãos angulosos; cimento argiloso e silicoso(?). Estrutura não evidente. Argilito - textura clästica com partículas menores que 0,002 mm. Estratificação incipiente; composição, argila. Rocha coerente.Are nito conglomerätico - semelhante ao anterior exceto pela cor e incoerência pronunciada das partículas.Argilito semelhante ao anterior exceto pela cor. Sedimentos Mode $\underline{r}$ nos - Pedissedimentos e recobrimentos detriticos razos, provenientes principalmente de gnaisse. 


$$
4.1 \text { - SOLOS }
$$

Os perfis de solos escolhidos para as anälises mineralögicas pertencem as principais unidades de solo descritas no trabalho de CARVALHO et a1., (1972), confor me mapa (Figura 2). Selecionaram-se onze perfis de solo de uma topossequência assinalada pela linha AB(Figura 3 ). A sequência detalhada dos solos estudados encontra-se es quematizada na Figura 3. Tais solos são derivados princi palmente de recobrimentos detríticos rasos sobre gnais ses e tambëm solos desenvolvidos de material remanejado, granitos, granitos/gnaisses e um perfil sobre micaxisto (Figura 4).

A topossequência escolhida abrange solos de regiões altas com $1.100 \mathrm{~m}$ de altitude e regiōes mais baixas com altitude aproximada de $750 \mathrm{~m}$. Incluiu-se, eviden 
temente,solos em posição topogräfica intermediária.

Os solos das regiões altas são rasos ou pouco desenvolvidos e representados pelos nümeros 1 e 2 na Figura 3. O solo 1 é um complexo formado por duas unidades, Itapetinga e Rio Acima sendo aquela um Litossolo substrato granito e esta um Podzólico com cascalho em que em ambas é comum se notar afloramentos da rocha, no caso granito.

Segue-se o solo de $n^{\circ} 2$ (Figura 3), topografica mente inferior e que é uma transição entre Podzólico Ver melho Amarelo para Latossolo Vermelho Amarelo e que ainda conserva a estrutura da rocha matriz. Os solos 3,4 e 5 (Figura 3) são Podzólicos Vermelho Amarelo orto e se situam em regiões ainda elevadas porém com vertentes menos ingremes, principalmente o de $n^{\circ} 4$ (unidade Cachoeira).

Os solos 6 e 7 são acentuadamente drenados situando-se nas colinas mais baixas da região. São latossolos representados pelas unidades piqueri e Tanaue (Figura 3).

Os estudos mineralógicos foram realizados em amostras de três ou quatro horizontes selecionados de cạ da um desses perfis, totalizando trinta e cinco amostras.

Nos casos em que foram verificadas descontinuidades litológicas (recobrimento) foram também tomadas 
amostras dos horizontes situados nos dois diferentes materiais de origem para se verificar os estägios de intem perização desses solos.

Os solos foram classificados segundo o Serviço Nacional de Pesquisas Agronômicas (1960) e pelo "Soil Survey Staff" (1960); as unidades estudadas podem ser re sumidas da seguinte maneira:

Unidade Itapetinga (Perfil 1011) - Litossolo fa se substrato granito/gnaisse, pertencente a ordem Inceptissolo. São solos pouco desenvolvidos, bem drenados,áci dos e com baixa saturação de bases; apresentam epipedon ôcrico assente sobre um horizonte câmbico. O horizonte câmbico (B) apresenta pontuações de mineral alterado (feldspato).

Unidade Rio Acima (Perfil 1037) - Esta unidade enquadra-se no grande grupo dos solos Podzolizados com cascalhos e na ordem U1tissolo. São solos minerais pouco profundos, bem drenados, ácidos, com saturação de bases muito baixas e nítida diferenciação entre os horizontes A e B. Apresentam epipedon ócrico sobre horizonte argíli co. Separando esses horizontes é frequente a concentra ção de fragmentos de rocha decomposta e de quartzo.

Os solos dessas duas unidades desenvolvem-se di retamente sobre um granito pegmatítico, sem evidência de recobrimento espesso. 


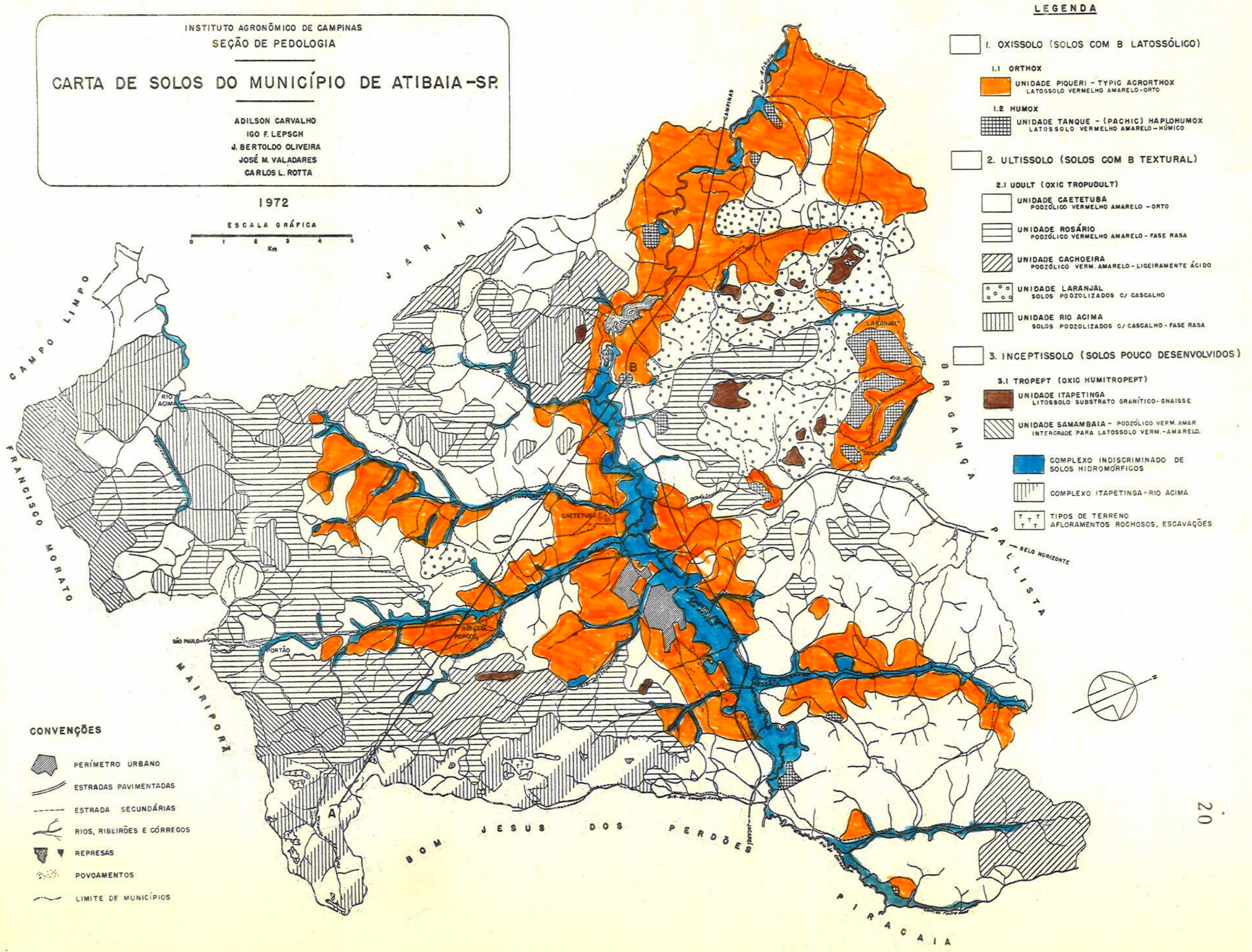




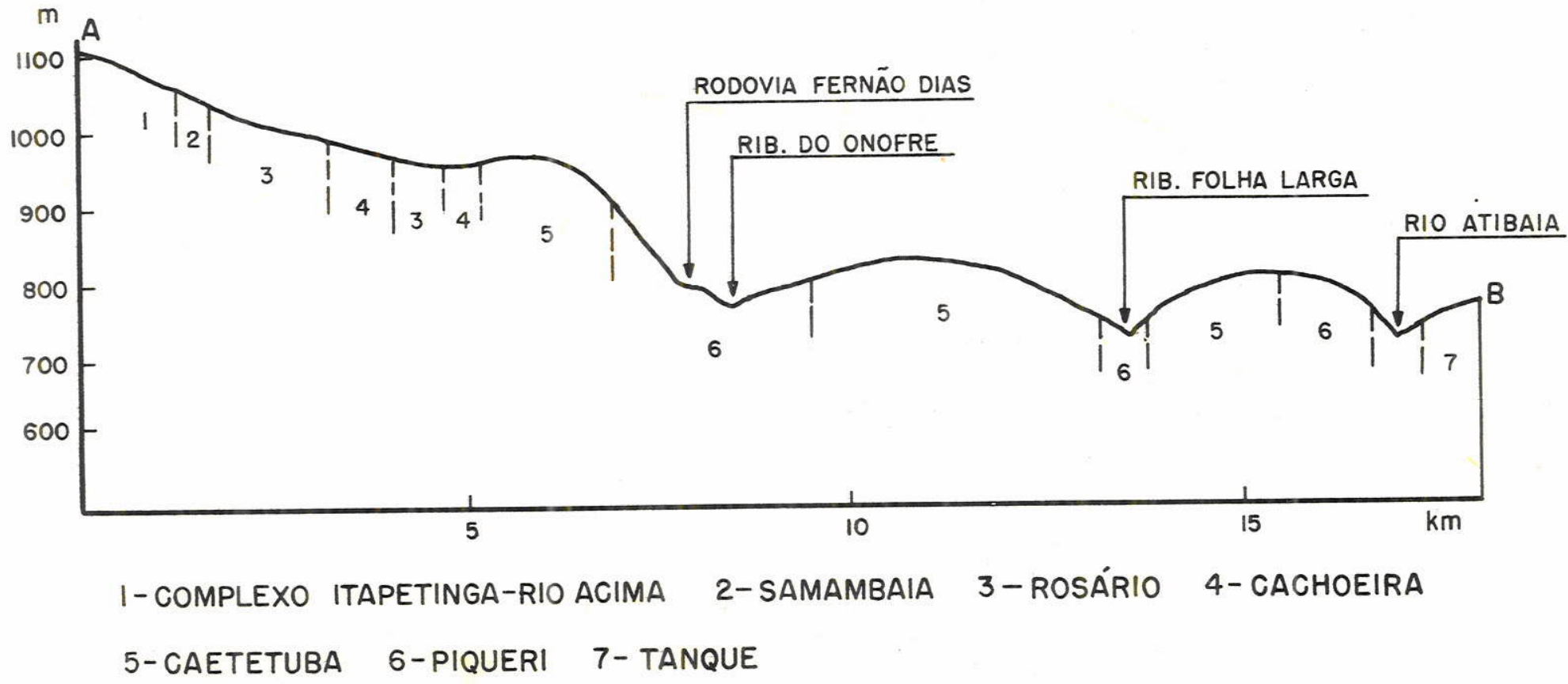

Figura 3 - Secção esquemática mostrando a distribuição no relevo e a sequência das unidades de solo 


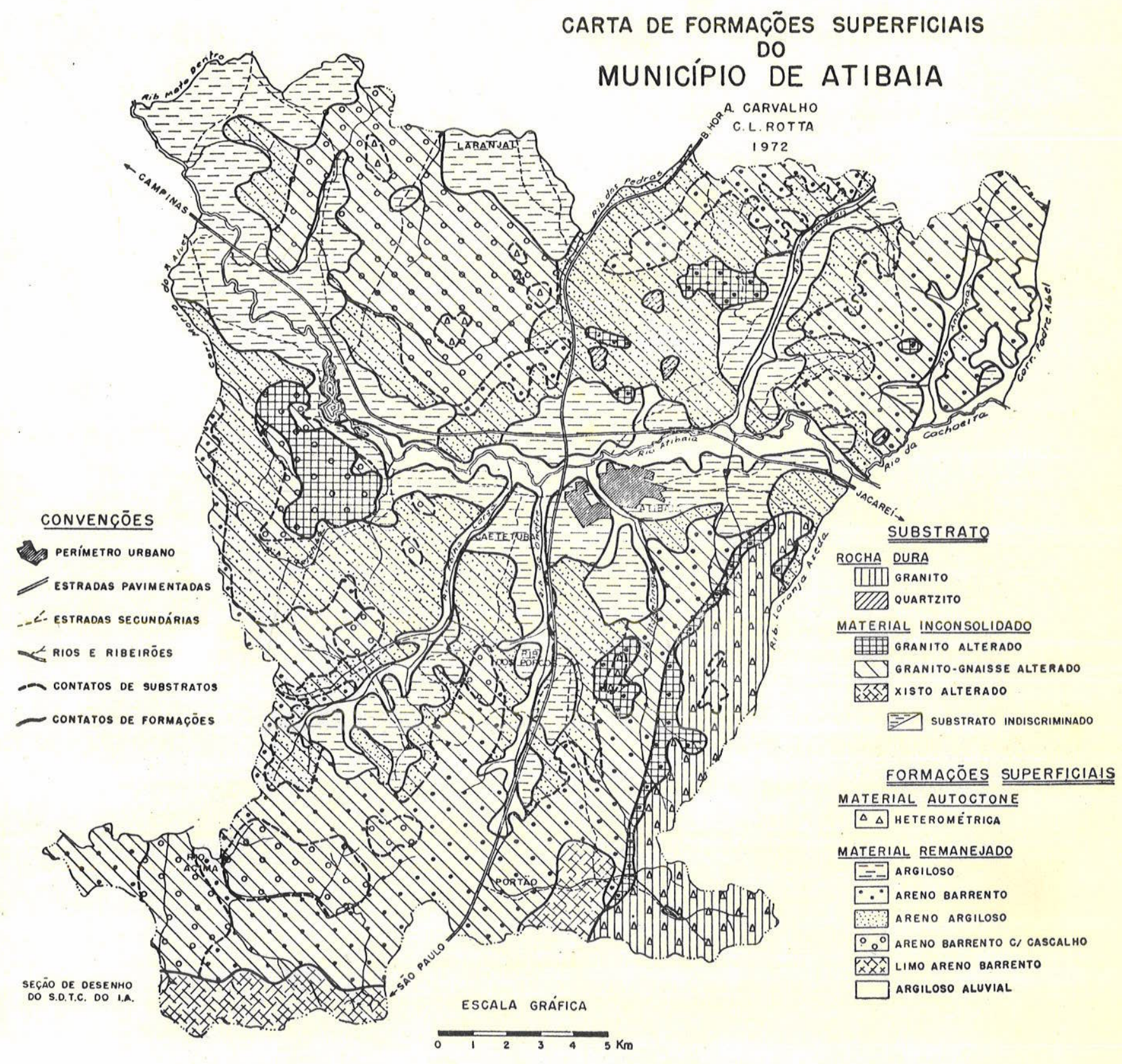


Unidade Samambaia (Perfil 1032) - Os solos des ta unidade são minerais, pouco desenvolvidos, com um epi pedon ócrico assente sobre um horizonte câmbico. E comum a ocorrência de linhas de pedras constituídas de fragmen tos de quartzo arestados. Neste perfil aparece o xisto meteorizado, de coloração variegada e com a estrutura original conservada. Esses solos correspondem à unidade Podzólico Verme1ho Amarelo "intergrade" para Latossolo Verme 1ho Amare1o enquadrando-se na ordem dos Inceptissolos.

Unidade Rosärio (Perfil 1055) - Esta unidade é constituída por solos minerais rasos (profundidade efet va de $50 \mathrm{~cm}$ ) e marcante diferenciação entre horizontes. os horizontes superficiais formam um epipedon ócrico que está assente sobre um horizonte argíiico. E encontrada uma linha de pedras no horizonte B2. Assemelha-se ao Pod zölico Vermelho Amarelo orto e U1tissolo.

Unidade Cachoeira (Perfis 1034 e 1054) - Esta unidade apresenta solos minerais, bem drenados e com mar cante diferenciação entre os horizontes; é encontrada também linha de pedras a profundidades variadas, com um epipedon ócrico sobre horizonte argílico. Esta unidade enquadra-se no Grande Grupo Podzólico Vermelho Amarelo orto e Ultissolo.

Unidade Caetetuba (Perfis 1064 e 1052) - Esta unidade apresenta solos minerais, moderadamente profundos e forte diferenciação dos horizontes A e B. E constí 
tuída por um epipedon ócrico assente sobre um horizonte argílico. Separando o horizonte argílico do horizonte B3 ou C é encontrada uma linha de fragmentos de quartzo arestado. Trata-se de um Podzólico Vermelho Amarelo orto e Ultissolo.

Unidade Piqueri (Perfis 1031 e 1051) - Estes so los se enquadram entre os Latossolos Vermelho Amarelo or to e pertence a ordem dos oxissolos. São solos minerais, acentuadamente drenados com pequena diferenciação de horizontes. As camadas superficiais compõem um epipedon ócrico, que estả assente sobre um horizonte óxico. Apresenta na parte inferior do horizonte óxico uma linha de fragmentos de quartzo arestados e em alguns casos rolados juntamente com fragmentos de canga laterítica. Este perfil atinge o horizonte $C$ de gnaisse intemperizado,con servando em grande parte a estrutura original da rocha.

Unidade Tanque (Perfil 1063) - Os solos dessa unidade são minerais, muito profundos, pouca diferenciação de horizontes e epipedon úmbrico sobreposto a um horizonte óxico. Esta unidade enquadra-se como Latossolo Vermelho Amarelo Hümico e Oxissolo.

4.2 - METODOS

4.2.1 - PRE-TRATAMENTO E SEPARAÇÕES PARA AS ANALISES DAS AMOSTRAS

os métodos empregados para as anảlises mineraló 
gicas constam da Figura 5.

Foram tomadas cerca de $20 \mathrm{~g}$ de terra fina seca ao ar (fração menor que $2 \mathrm{~mm}$ ) c colocadas em solução tam pão $\mathrm{pH} 5$ com água oxigenada, seguindo o método descrito por JACKSON (1969), para remoção da matéria orgânica e mang anês.

Foi efetuada a remoção de óxidos de ferro livre, utilizando-se o método do ditionito-citrato-bicarbonato de sódio, descrito por MEHERA \& JACKSON (1969).

As amostras livres de matëria orgânica, foram adicionados $40 \mathrm{ml}$ de citrato de sódio $0,3 \mathrm{M}$ e $5 \mathrm{ml}$ de bicarbonato de sốdio $1 M$ e $1 \mathrm{~g}$ de ditionito de sódio. $0 \cdot c i-$ trato como agente complexante do ferro, o bicarbonato co mo tampão e o ditionito como redutor. Esta solução foi aquecida a $75-80^{\circ} \mathrm{C}$ por quinze minutos. Após estes tratamentos as amostras foram lavadas tantas vezes quantas ne cessärias com $\mathrm{NaCl} 0,5 \mathrm{~N}$ que tem a finalidade de flocular a argila permitindo sifonar o sobrenadante contendo 0 ferro complexado.

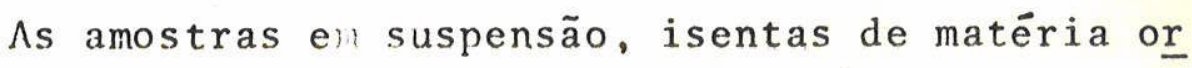
gânica, óxidos de ferro livre e de manganês, foram sepa radas em tamis de $0,053 \mathrm{~mm}$. A fração maior que aquele diâmetro foi reservada para exame ao microscópio polarizador, montadas em lâminas com índice de refração conhecido, enquanto a menor foi guardada em suspensão. 


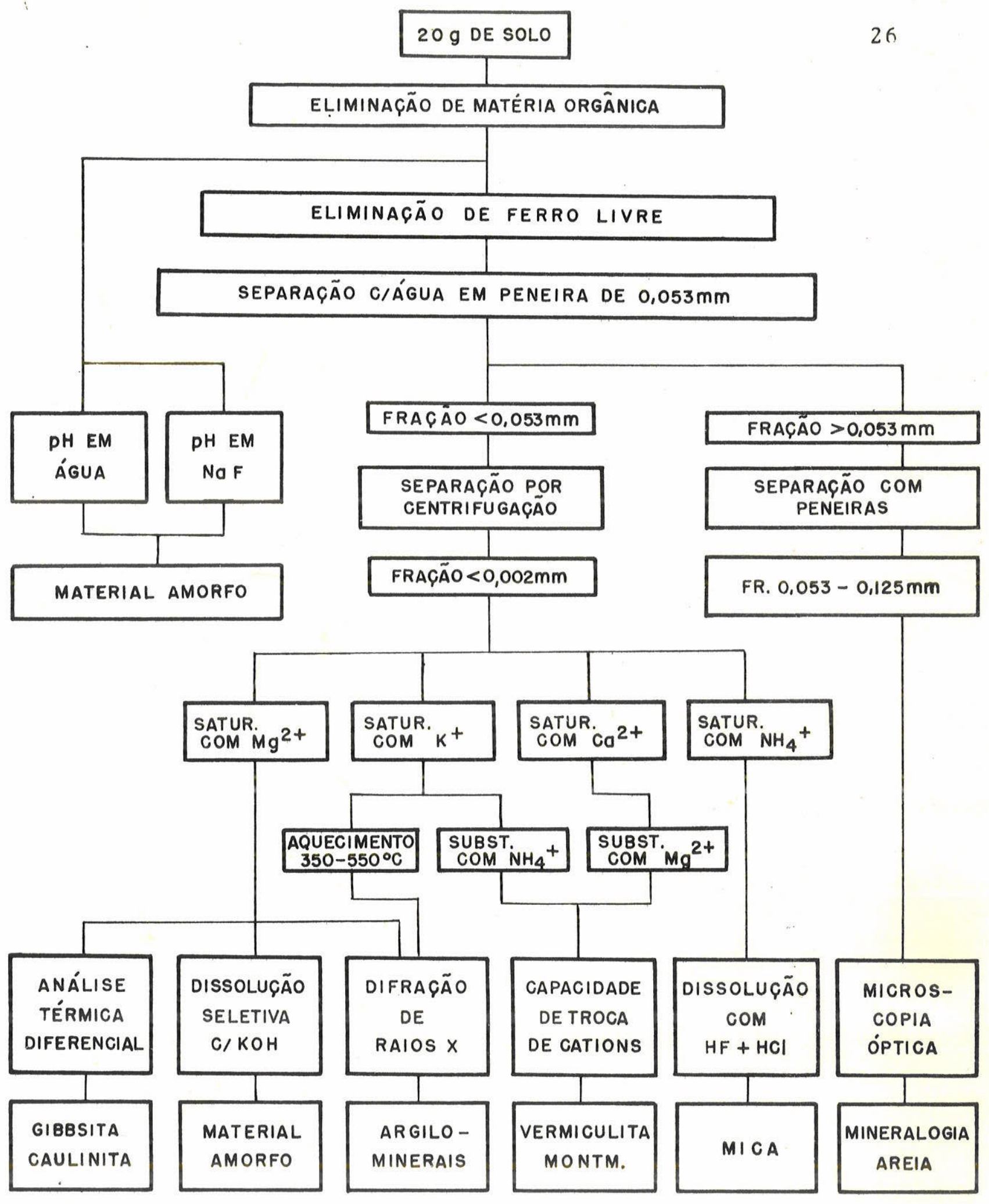

Figura 5 - Fluxograma das anảlises mineralógicas 
Esta suspensão contendo silte mais argila foi transferida para tubos de centrífuga e a fração argila (menor que $0,002 \mathrm{~mm}$ ) foi separada a 750 rpm durante 2,7 minutos numa centrífuga internacional de $n^{9} 2$.

JACKSON (1969), recomenda para determinações com raios $X$, que uma alíquota da suspensão de argila seja tratada com $\mathrm{MgCl}_{2} \underline{\mathrm{N}}$ para remover os acetatos. Para isso transferiu-se uma alíquota da suspensão de argila para tubos de centrífuga de $15 \mathrm{~m} 1$ centrifugando-se a $1800 \mathrm{rpm}$ durante cinco minutos, JACKSON (1964). Procederam-se cin co saturações com ions magnésio acompanhadas de centrifu gação e em seguida o excesso de sal foi lavado da seguin te forma: uma lavagem com água distilada, uma com âlcool etílico e água e finalmente uma com ảlcool etílico, todas as operações seguidas por centrifugação. Testou-se a eliminação completa de cloretos com $\mathrm{AgNO}_{3}$ a $1 \%$ no final das 1 avagens. Recomenda-se, também, JACKSON (1969) qua as amostras a serem aquecidas a $350^{\circ} \mathrm{C}$ e $550^{\circ} \mathrm{C}$, sejam tratadas com KCl.

o tratamento da fração argila com cloreto de potássio é idêntico ao item anterior.

As argilas tratadas com magnésio, ainda úmidas, foram saturadas com etileno glicol e com auxílio de uma espátula foram orientadas preferencialmente em lâminas de vidro.

As saturadas com ions potássio tambểm foram or $\underline{i}$ 
entadas preferencialmente e aquecidas a 350 e $550^{\circ} \mathrm{C}$.

Após cada um desses tratamentos, ou seja: saturação com magnésio, potässio, aquecimento, as amostras foram irradiadas com raios-X no intervalo de $2-28^{\circ}$ em aparelho com tubo de cobre e filtro de níque1.

De posse dos difratogramas passou-se a identifi cação dos principais minerais de argila seguindo-se os trabalhos de BRINDLEY (1955) e JACKSON (1969). A difração dos raios-X é uma das técnicas mais seguras de identificação de minerais de argila, sendo possível identifi car os componentes mineralögicos de uma mistura, até mesmo daqueles presentes em pequenas proporções. Baseia-se fundamentalmente na determinação dos espaçamentos interplanares, d, característicos de cada minera1. Assim, de acordo com a dimensão de seus principais espaçamentos ba sais, os argilominerais podem ser grupados em três categorias principais de $14 \AA$, de $10 \AA$ e de $7,2 \AA$, BRINDLEY (1955). A vermiculita e montmorilonita, ambas com $14 \AA$, contraem-se para $11 \AA$ com o aquecimento a $350^{\circ} \mathrm{C}$ porém so mente a montmorilonita se expande para $17-18 \AA$ quando tratada com etileno glicol ou glicerol. A clorita também, com espaçamento de $14 \AA$ aumenta a intensidade do seu espaçamento de $14 \AA$, quando aquecida a $550^{\circ} \mathrm{C}$.

No grupo dos minerais de $10 \AA$, os minerais do grupo de mica não sofrem nenhuma alteração com tais tratamentos. A caulinita com seus espaçamentos característi $\cos$ de $7,2 \Omega$ e $3,5 \AA$ é eliminada a $550^{\circ} \mathrm{C}$ e a gibbsita 
identificada pelo espaçamento de $4,8 \AA$ é destruida a $350^{\circ} \mathrm{C}$.

4.2.2 - ANALISE DUANTITATIVA DOS MINERAIS DA FRAÇ̊̊ ARGILA

Foram determinados quantitativamente: caulinita, gibbsita, material amorfo, mica, vermiculita e mont morilonita (Ouadro 1).

A caulinita e gibbsita foram determinadas por anälise térmica diferencial, empregando-se o descrito por DIXON (1966). O gradiente de temperatura usado foi de aproximadamente $10^{\circ} \mathrm{C} / \mathrm{minuto}$ e a temperatura mảxima foi de $650^{\circ} \mathrm{C}$. As amostras saturadas com ions magnésio foram misturadas na proporção de $20 \%$ com óxido de alumí nio previamente calcinado a $950^{\circ} \mathrm{C}$. A curva de calibração para caulinita foi obtida com caulinita da Flórida (Figura 6) e para gibbsita com gibbsita de Minas Gerais (Figura 7).

A percentagem de caulinita foi obtida pela equação:

$\because$ cau1. $=\frac{\text { caulinita obtida na curva de calibração }}{\frac{0}{0} \text { dargila na mistura com } A 1_{2} \mathrm{O}_{3}} \times 100$

A percentagem de gibbsita foi calculada pela equação:

$$
\because \text { gib. }=\frac{\text { gibbsita obtida na curva de calibração }}{\frac{0}{0} \text { argila na mistura com } \mathrm{Al}_{2} \mathrm{O}_{3}} \times 100
$$




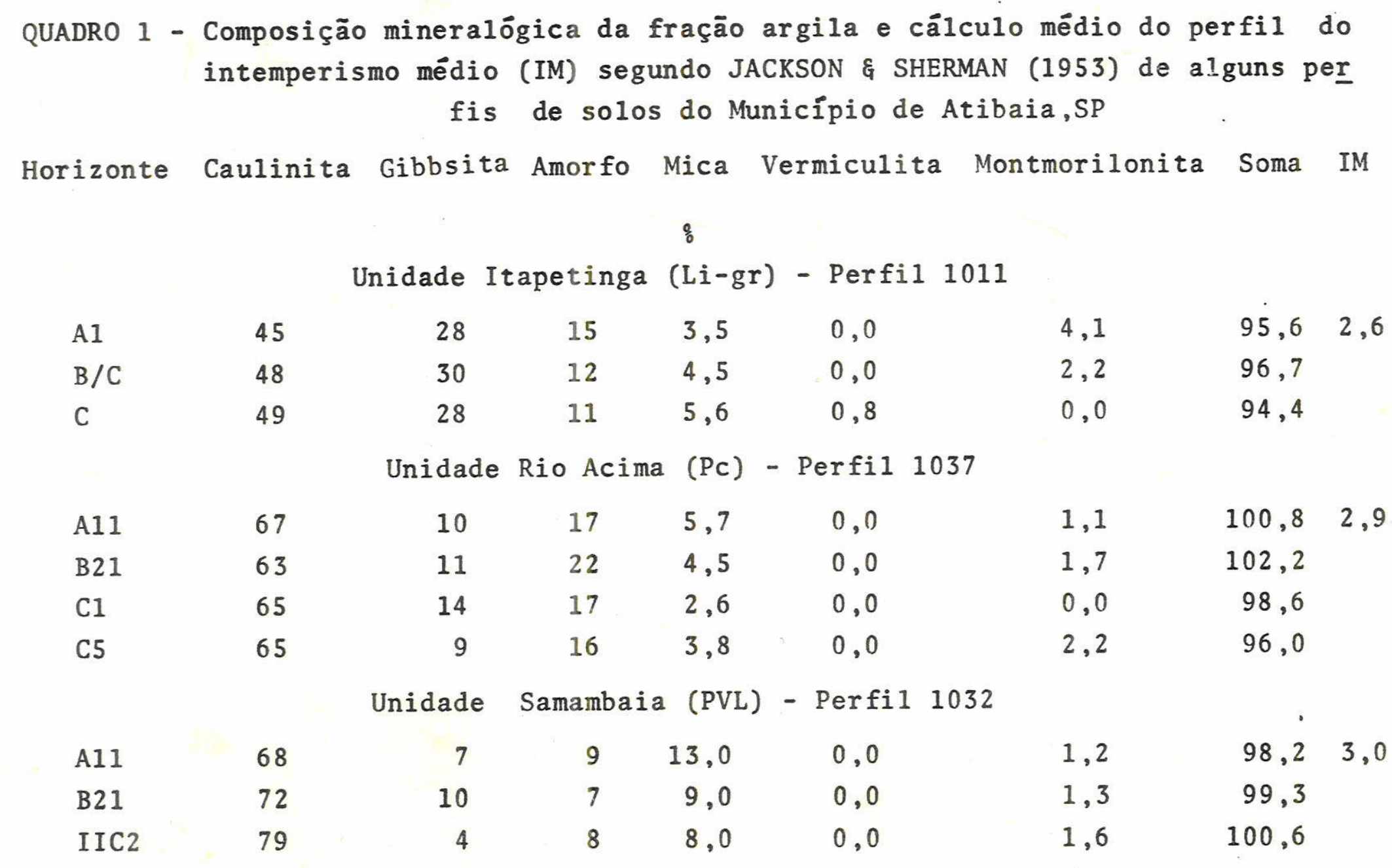




\begin{tabular}{|c|c|c|c|c|c|c|c|c|}
\hline Horizonte & Caulinita & Gibbsita & Amor fo & $\begin{array}{c}\text { Mica } \\
:\end{array}$ & Vermiculita & Montmorilonita & Soma & IM \\
\hline & & Unidade & Rosário & $(P V)-$ & - Perfil 1055 & & & \\
\hline Ap & 60 & 10 & 11 & 11,3 & 0,0 & 1,8 & 94,1 & 3,2 \\
\hline B2 & 67 & 8 & 16 & 9,6 & 0,0 & 1,9 & 102,5 & \\
\hline \multirow[t]{2}{*}{ I IC2 } & 78 & 4 & 16 & 4,5 & 0,5 & 0,0 & 103,0 & \\
\hline & & Unidade $C$ & Cachoeira & $(\mathrm{PV})$ & - Perfil 1034 & & & \\
\hline Ap & 73 & 4 & 16 & 3,8 & 0,3 & 0,0 & 97,1 & 3,1 \\
\hline B1 & 66 & 9 & 16 & 4,7 & 0,0 & 0,9 & 96,6 & \\
\hline I I B22 & 68 & 7 & 20 & 1,7 & 0,0 & 2,5 & 99,2 & \\
\hline \multirow[t]{2}{*}{ I IC 3} & 73 & 4 & 20 & 3,6 & 0,6 & 2,1 & 103,3 & \\
\hline & & Unidade C & Cachoeira & (PV) & - Perfil 1054 & & & \\
\hline $\mathrm{A} 1$ & 69 & 4 & 15 & 12,7 & 0,0 & 2,0 & $102, ?$ & 3,5 \\
\hline B22 & 61 & 6 & 24 & 5,6 & 1,0 & 1,9 & 99,5 & \\
\hline \multirow[t]{2}{*}{ I IC2 } & 73 & 1 & 19 & 6,9 & 0,0 & 2,0 & 101,9 & \\
\hline & & Unidade $C$ & Caetetuba & $(\mathrm{PV})$ & - Perfil 1064 & & & \\
\hline Ap & 73 & 4 & 16 & 1,1 & 0,0 & 1,8 & 95,9 & 4,2 \\
\hline B22 & 82 & 3 & 14 & 1,2 & 0,0 & 2,2 & 102,4 & \\
\hline I I C.I & 83 & 1 & 17 & 1,7 & 0,0 & 1,9 & 103,6 & \\
\hline
\end{tabular}




\begin{tabular}{|c|c|c|c|c|c|c|c|c|}
\hline Horizonte & Caulinita & Gibbsita & Amorfo & $\begin{array}{c}\text { Mica } \\
\vdots\end{array}$ & Vermiculita & Montmorilonita & Soma & IM \\
\hline & & Unidade $\mathrm{C}$ & Caetetuba & $(P V)-$ & - Perfil 1052 & & & \\
\hline Ap & 85 & 5 & 10 & 1,7 & 0,0 & 4,2 & 105,9 & 3,3 \\
\hline B22 & 74 & 7 & 12 & 2,2 & 0,0 & 3,0 & 98,2 & \\
\hline \multirow[t]{2}{*}{ I IC2 } & 72 & 9 & 9 & 2,6 & 0,0 & 6,5 & 99,1 & \\
\hline & & Unidade & Piqueri & $(L V)-$ & Perfil 1051 & & & \\
\hline $\mathrm{A} 1$ & 64 & 17 & 15 & 3,6 & 3,5 & 0,0 & 103,1 & 5,0 \\
\hline B22 & 57 & 20 & 15 & 3,0 & 0,7 & 0,0 & 95,7 & \\
\hline \multirow[t]{2}{*}{ I IC 3} & 82 & 4 & 13 & 4,0 & 0,5 & 1,5 & 105,0 & \\
\hline & & Unidade & Piqueri & $(L V)-$ & Perfil 1031 & & & \\
\hline A11 & 65 & 17 & 12 & 2,1 & 0,0 & 0,9 & 97,0 & 5,3 \\
\hline B21 & 57 & 16 & 19 & 2,3 & 0,0 & 1,6 & 95,9 & \\
\hline \multirow[t]{2}{*}{ I IC3 } & 84 & 0 & 14 & 3,6 & 0,0 & 0,0 & 101,6 & \\
\hline & & Unidade & Tanque & $(\mathrm{LH})-$ & Perfil 1063 & & & \\
\hline A12 & 73 & 7 & 12 & 1.7 & 0,6 & 0,0 & 94,3 & 5,6 \\
\hline B2 & 71 & 12 & 12 & 1,9 & 0,5 & 0,0 & 97,4 & \\
\hline B3 & 71 & 9 & 12 & 1,9 & 0,8 & 0,0 & 94,7 & \\
\hline
\end{tabular}




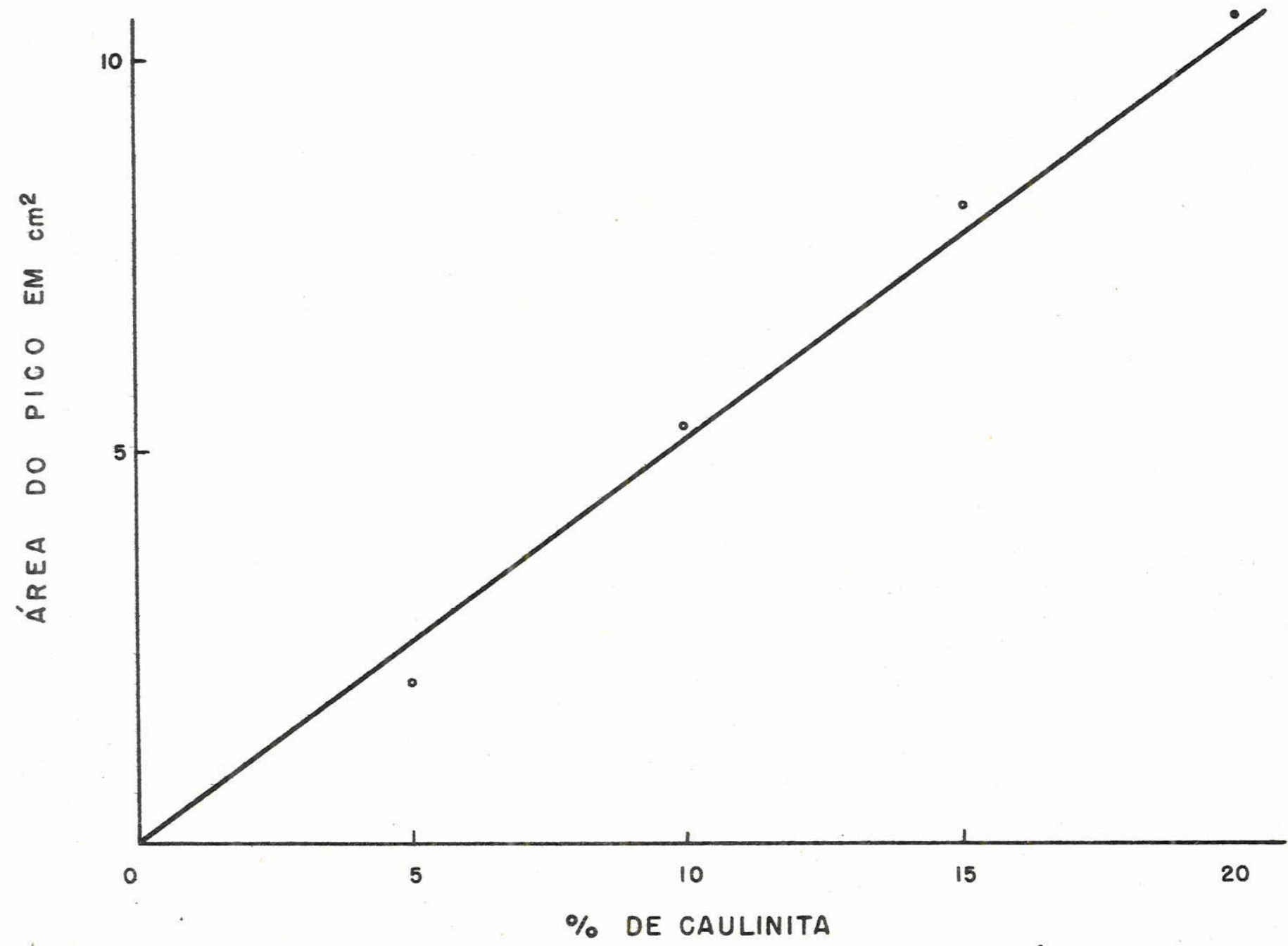

Figura 6 - Curva de calibração para caulinita por anālise térmica diferencial w 


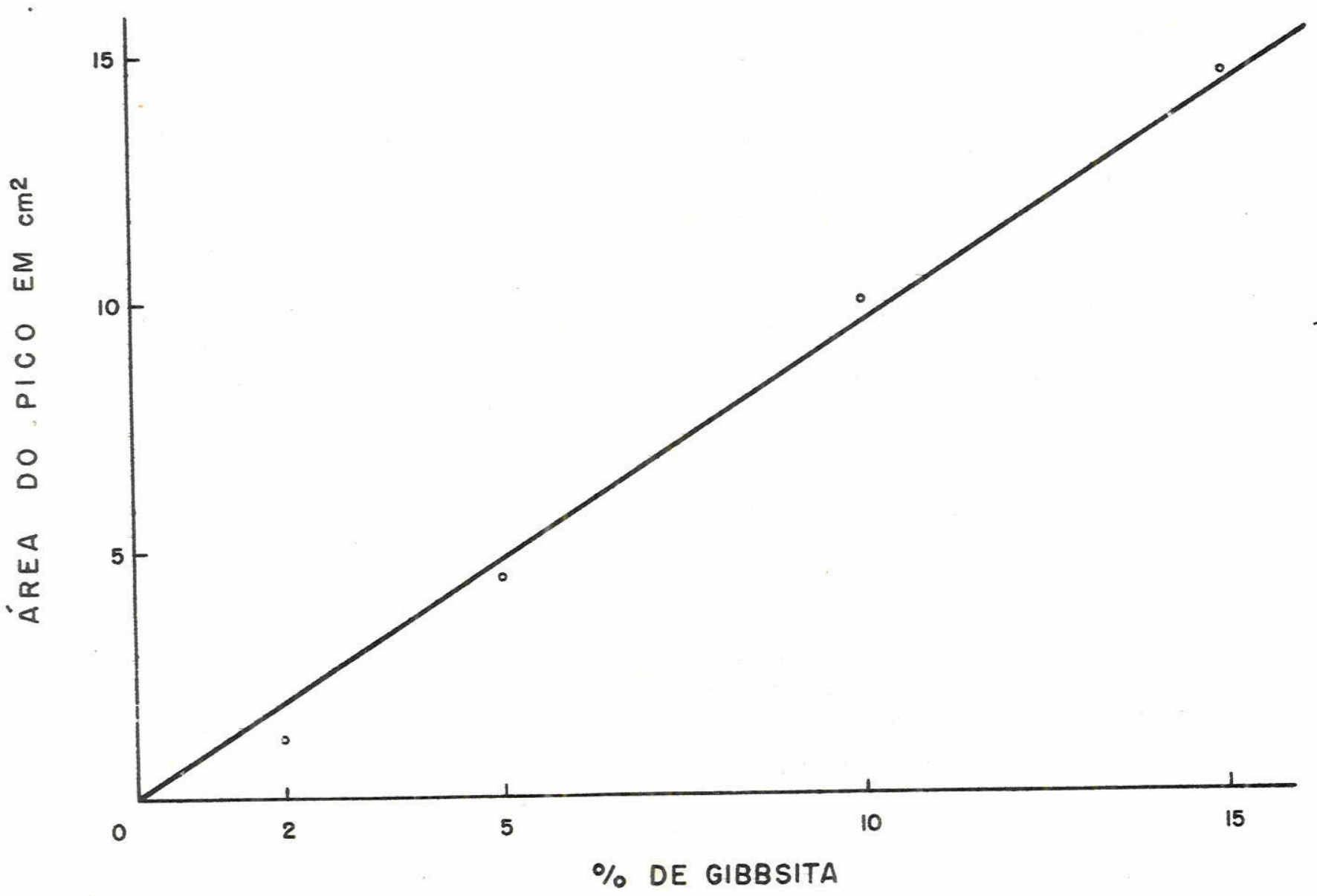

Figura 7 - Curva de calibração para gibbsita por anảlise térmica diferencial 
0 teor de material amorfo foi determinado por dois métodos: o da dissolução seletiva, proposto por HASHIMOTO \& JACKSON (1960) modificado por CARVALHO (1971) e por DUDAS \& HARWARD (1971), que introduziram KOH $0,5 \mathrm{~N}$ em vez de $\mathrm{NaOH}$, e, o método do tratamento do solo por NaF, FIELDS \& PERROTT (1966).

Para o primeito método a anālise foi realizada em amostras de argila $(0,1 \mathrm{~g})$, saturadas com magnésio, previamente moídas e secas a $110^{\circ} \mathrm{C}$. Determinou-se a percentagem de silício pelo mëtodo do ácido sulfomolíbdico amarelo, JACKSON (1964) e alumínio pelo método do aluminon, HSU (1963). As leituras desses elementos foram feitas em colorímetro com filtros específicos para cada ele mento analisado. Calculados os teores de $\mathrm{SiO}_{2}$ e $\mathrm{Al}_{2} \mathrm{O}_{3}$ (subtraindo-se $\circ \mathrm{Al}_{2} \mathrm{O}_{3}$ devido à gibbsita) acrescentou-se 208 (do total de $\mathrm{SiO}_{2}+\mathrm{Al}_{2}{ }_{3}$ ) que corresponde à água. Com a soma desses três componentes obteve-se a percentagem de material amorfo (Quadro 1).

Para o segundo método usou-se $1 \mathrm{~g}$ de solo trata do com ăgua oxigenada (eliminação de matêria orgânica). Determinou-se o $\mathrm{pH}$ desse solo em água e posteriormente em NaF N. Os valores de material amorfo foram estimados segundo os valores de $\mathrm{pH}$ encontrados, Quadro 2. Assim pa$\mathrm{ra}$ pH da amostra em NaF menor que 8,8 tem-se menos que 5: de amorfo (o papel de filtro com fenolftaleina permanece incolor em presença do extrato de $\mathrm{NaF}$ ); para $\mathrm{pH}$ entre 8,8 e 9,0 tem-se 5 a $7 \%$ de amorfo (o papel de filtro torna-se levemente róseo); para valores de pH acima de 
QUADRO 2 - Teores de material amorfo do solo livre de ma têria orgânica determinados pelo teste räpidó de FIELDS \& PERROTT, 1966

Horizonte $\mathrm{pH}$ em água $\mathrm{pH}$ em NaF $\begin{aligned} & \text { Percentagem de } \\ & \text { material amorfo }\end{aligned}$

Unidade Itapetinga (Perfil 1011)

$\begin{array}{llll}\mathrm{A} 1 & 4,55 & 9,25 & >7 \\ \mathrm{~B} / \mathrm{C} & 4,55 & 9,28 & >7 \\ \mathrm{C} & 4,48 & 9,35 & >7\end{array}$

Unidade Rio Acima(Perfil 1037)

A11

B21

C1

C 5

$$
4,57
$$

9,20

$>7$

4,45

9,75

$>7$

4,21

9,45

$>7$

4,10

9,75

$>7$

Unidade Samambaia(Perfil 1032)

A11

4,61

8,80

$<5$

B21

4.85

9,70

$>7$

I IC 3

4,37

8,60

$<5$

Unidade Rosārio(Perfil 1055)

Ap

B2

$$
5,38
$$

8,90

I IC2

4.84

9,80

$>7$

$>7$

Unidade Cachoeira(Perfil 1034)

Ap

B1

I I B22

I IC 3
4,35

4,35

4,33

4,68
8,95

8,90

9,50

9,40
$5-7$

5-7

$>7$

$>7$ 
QUADRO 2 - (continuação)

Horizonte $\mathrm{pH}$ em ăgua $\mathrm{pH}$ em NaF $\begin{aligned} & \text { Percentagem de } \\ & \text { material amorfo }\end{aligned}$ Unidade Cachoeira (Perfil 1054)

A1

B22

4,45

9,00

$>7$

I IC2

4,45

9,70

$>7$

4,50

9,15

$>7$

Unidade Caetetuba (Perfil 1064)

Ap

B22

4,55

8,55

$<5$

IIC 1

4,30

9,05

$>7$

4,22

8,45

$<5$

Unidade Caetetuba (Perfil 1052)

Ap

B22

I IC 2

A1

B22

I IC 3

A11

B21

IIC3

A12

B2

B3

4,55

4,10

4,34

8,65

9,10

8,90

$>7$

$5-7$

Unidade Piqueri (Perfil 1051)

$\begin{array}{rrr}4,40 & 9,40 & >7 \\ 5,12 & 10,10 & >7 \\ 4,37 & 9,10 & >7\end{array}$

Unidade Piqueri (Perfil 1031)

4,41

9,23
10,10
8,50

$>7$

5,14

5,09

8,50

$>7$

$<5$

Unidade Tanque (Perfil 1063)

$\begin{array}{lll}4,55 & 9,50 & >7 \\ 4,10 & 9,95 & >7 \\ 4,06 & 9,60 & >7\end{array}$


9,0 tem-se mais de $7 \%$ de amorfo (o papel de filtro se torna vermelho).

Para obtenção quantitativa de mica,vermiculita e montmorilonita procedeu-se a um pré tratamento.

As argilas em suspensão foram novamente tratadas com ảgua oxigenada a $30 \%$ e acetato de sódio a pH 5 . Em seguida foram saturadas 5 vezes com cloreto de magnésio $N$, retirando-se o excesso de cloreto ALEXIADES \& JACKSON (1965). Nos casos em que ocorreu dispersão, ut 1izou-se tambëm acetona. $\Lambda$ eliminação dos sais foi veri ficada com $\mathrm{AgNO}_{3}$ a $1 \%$. As amostras foram transferidas quantitativamente para cadinhos de platina e/ou teflon, secas a $110^{\circ} \mathrm{C}$ para determinação da concentração de argi 1 a da suspensão.

Para a determinação de nica (Cuadro 1) tomouse uma alíquota de peso conhecido de cada amostra pipetando-se a suspensão de argila e colocando-as em cadinhos de platina e/ou teflon, secando-as a $110^{\circ} \mathrm{C}$ por 2 horas. Em seguida foram atacadas com $\mathrm{HF} 48 \%$ e $\mathrm{HC} 16 \mathrm{~N}$ e aquecidas a $200-230^{\circ} \mathrm{C}$ atê a completa dissolução. Após este tratamento transferiu-se o material dissolvido pa$\mathrm{ra}$ balões de $100 \mathrm{ml}$ tomando-se aliquotas para determina ção do potássio tota1, no fotômetro de chama. O teor de mica foi obtido considerando-se que a percentagem de $10 \%$ de $\mathrm{K}_{2} \cap$ correspondem $1 \cap 0 \%$ de mica, JACKSON (1964).

$\Lambda$ determinação de montmorilonita foi feita pe- 
10 método da capacidade de troca de cations (CTC)pela sa turação da amostra com $\mathrm{K}^{+}$e sua substituição com lavagens com $\mathrm{NH}_{4}^{+}$. A percentagem de montmorilonita é determi nada pela förmula seguinte:

$\because$ montmorilonita $=\frac{\operatorname{CTC}\left(\mathrm{K} / \mathrm{NH}_{4}\right)-(5+105 \mathrm{Am})}{105} \times 100$

em que $A m=\frac{o}{o}$ de material amorfo.

Como a relação $\mathrm{SiO}_{2} / \mathrm{Al}_{2} \mathrm{O}_{3}$ em todas as amostras foi menor que 3 , o fator 105 do numerador foi eliminado conforme descreve o mëtodo de ALEXIADES \& JACKSON(1965).

A CTC medida pelo deslocamento do potássio não fixado atravês do $\mathrm{NH}_{4} \mathrm{Cl} \underline{\mathrm{N}}$ e designado $\mathrm{CTC}\left(\mathrm{K} / \mathrm{NH}_{4}\right)$, forne ce a percentagem de montmorilonita apỏs a dedução corres pondente das cargas de superfície externa de outros mine rais (Quadro 1). O potássio foi medido pelo fotômetro de chama.

Para a determinação da vermiculita (Quadro 1) saturaram-se as amostras com $\mathrm{Ca}^{2+}$ com posterior substituição por $\mathrm{Mg}^{2+}$. $\Lambda$ leitura do cálcio se fez através do espectrofotômetro de absorção atômica, usando-se 1antânio em solução final de $0,5 \circ$ para evitar a interferência do alumínio SLAVIN (1968). A percentagem de vermiculita se obteve pela equação seguinte:

vermiculita $=\frac{\mathrm{CTC}(\mathrm{Ca} / \mathrm{Mg})-\operatorname{CTC}\left(\mathrm{K} / \mathrm{NH}_{4}\right)}{154} \times 100$ 
4.2.3 - ANALISE DUUANTITATIVA DOS MINERAIS DA FRAÇÃO AREIA

Para essas anä1ises (Ouadro 3) tomou-se a fração $0,05 \mathrm{~mm}$ a $0,10 \mathrm{~mm}$ em que se processou a separação dos minerais pesados por meio de bromofórmio segundo KRUMBEIN \& PETTIJOHN (1938) e o emprego da centrífuga. Tendo em vista a pequena quantidade de pesados, optou-se pelo seu estudo conjuntamente com os leves.

Foram montadas lâminas com líquidos de indice de refração conhecido e contados em média trezentos grãos. A identificação foi feita pelos métodos usuais de öptica cristalogräficas segundo BLOSS (1961), ROGERS \& KERR (1942), HEINRICH (1965), DANA-HURLBUT (1969) e LEINZ E CAMPOS (1.968).

4.2.4 - MEOIA DE INTEMPERISMO COM BASE NA FRAÇÃO ARGILA

0 intemperismo médio proposto por JACKSON if SHERMAN (1953), é dado pelas seguintes relações:

$$
m_{1}=m \frac{x}{100} \text { e } m=\frac{\sum(p s)}{\sum(p)}
$$

em que: $m=$ média de intemperismo

$X=$ porcentagem da fração argila no solo

$m_{1}=$ nova média de intemperismo

$p=$ porcentagem de um mineral no solo

$S=$ estägio de intemperismo médio do mineral ao qual $\mathrm{p}$ se refere, de acordo com a sequência de intemperismo de JACKSON \& SHERMAN (1953). 
QUADRo 3 - Composição mineralögica da fração areía $(0,1-0.05 \mathrm{~mm})$ e razão de intemperismo dos minerais leves (RIL) segun do RUUHE (1956) de alguns perfis de solos do município de Atibaia, SP

Horizonte Quartzo Ortocläsio Plagiocläsio Mica zircão Turmalina Sillimanita Opacos Concreçöes Qz/Felds 1

Unidade Itapetinge (Li-gr) - Perfil 1011

52
59
42

$\begin{array}{rrrr}2 & t r & t r & 4 \\ 4 & 8 & 0 & 1 \\ 2 & 33 & 0 & 0\end{array}$

0
0
0

$\begin{array}{rl}t r & 2 \\ 2 & 0 \\ 1 & 0\end{array}$

0.72

2

Unidade Rio Acima (Pc) - Perfil 1037

$\begin{array}{llr}\text { A1 } & 39 & 52 \\ \text { B/C } & 25 & 59 \\ \text { C } & 21 & 42 \\ & & \\ \text { A11 } & 73 & 18 \\ \text { B21 } & 75 & 20 \\ \text { C1 } & 52 & 42 \\ \text { C5 } & 48 & 38 \\ & & \\ \text { A11 } & 99 & 0 \\ \text { B21 } & 99 & 0 \\ \text { IIC3 } & 53 & 0 \\ & & \\ \text { Ap } & 91 & 9 \\ \text { B2 } & 95 & 5 \\ \text { IIC2 } & 62 & 10 \\ & & \\ \text { Ap } & 68 & 2 \\ \text { B1 } & 71 & 5 \\ \text { IIB2 } & 74 & 4 \\ \text { IIC3 } & 40 & 4\end{array}$

18.

42

38

$\begin{array}{lrr}\wedge 1 & 66 & 7 \\ B 22 & 63 & 6 \\ 11 C 2 & 21 & 2 \\ & & \\ \text { ip } & 98 & -2 r \\ B 22 & 93 & 35 \\ 11 C 1 & 55 & 145\end{array}$

$\begin{array}{lll}\text { Ap } & 71 & 0 \\ \text { B22 } & 81 & 0 \\ \text { IIC2 } & 47 & 3\end{array}$

$\begin{array}{llr}\text { A1 } & 93 & 0 \\ \text { B22 } & 91 & 1 \\ \text { IIC3 } & 72 & 23\end{array}$

$\begin{array}{lrr}\text { A11 } & 59 & 0 \\ \text { B21 } & 94 & 0 \\ \text { IIC3 } & 42 & 44\end{array}$

$\begin{array}{lll}\text { A12 } & 84 & 1 \\ \text { B2 } & 42 & 0 \\ \text { B3. } & 17 & 0\end{array}$$$
\begin{array}{lcccc}
0 & 4 & 0 & 0 \\
1 & \text { tr } & 1 & 0 \\
2 & \text { tr } & 0 & 0 \\
3 & 9 & 0 & 0 \\
\multicolumn{1}{c}{\text { Unidade }} & \text { Samambaia (PVL) } & - \text { Perfil } 1032 \\
0 & \text { tr. } & 0 & 0 \\
0 & 0 & 0 & t r \\
0 & 44 & 0 & 0
\end{array}
$$

0
0
0
0

$\begin{array}{rrr}4 & 0 & 4,05 \\ 3 & 0 & 3,56 \\ 3 & 0 & 1.18 \\ 2 & 0 & 1.17 \\ & & \\ 2 \pi & 0 & - \\ 8 x & 0 & -\end{array}$

$$
\begin{aligned}
& \text { Unidade Rosărio (PV) - Perfil } 1055 \\
& \begin{array}{rrrrrrrr}
0 & \text { tr } & 0 & \text { tr } & 0 & 0 & 0 & 10,10 \\
0 & \text { tr } & 0 & \text { tr } & 0 & \text { tr } & 0 & 19,00 \\
0 & .28 & 0 & 0 & 0 & 0 & 0 & 6,20 \\
& \text { Unidade Cachoeira (PV) } & - \text { Perfil } 1034 & & 0 &
\end{array}
\end{aligned}
$$

$\begin{array}{lrrlllll}0 & 1 & 1 & 1 & 0 & 0 & 15 & 34,00 \\ 0 & 12 & 4 & 0 & 0 & 7 & 0 & 14,20 \\ 0 & 8 & \text { tr } & 0 & 6 & 7 & 0 & 18,50 \\ 0 & 49 & \text { tr } & 0 & 0 & 6 & 0 & 10,00\end{array}$

\begin{tabular}{|c|c|c|c|c|c|c|c|}
\hline 0 & 17 & 0 & 0 & 0 & 10 & 0 & 9,40 \\
\hline 0 & 25 & 0 & 0 & 0 & 6 & 0 & 10.50 \\
\hline 0 & 74 & 0 & 0 & 0 & 2 & 0 & 10,50 \\
\hline & Caetetuba & (PV) & - Perfil 1064 & & & & \\
\hline 0 & 0 & 1 & 0 & 0 & $t r$ & 0 & 98,00 \\
\hline 0 & $\mathrm{~m} 0$ & 1 & $\operatorname{tr}$ & 0 & 2 & $t r$ & 31.00 \\
\hline 0 & 0 & 0 & 0 & 0 & tr & 0 & 1,22 \\
\hline
\end{tabular}

$$
\text { Unidade Cảchoeira (PV) - Perfiz } 1054
$$

Unidade Caetetuba (PV) - Perfil 1052

$\begin{array}{rrrrrrrr}0 & 4 & 1 & 0 & 8 & 16 & 0 & \text { - } \\ 0 & 5 & 5 & \operatorname{tr} & \operatorname{tr} & 8 & \operatorname{tr} & \text { - } \\ 0 & 36 & 13 & 0 & 0 & 1 & 0\end{array}$

Unidade Piqueri (LV) - Perfil 1051

$\begin{array}{rrrrrrrr}0 & 0 & \text { tr } & 0 & 0 & 6 & \text { tr } & - \\ 0 & 0 & \text { tr } & 0 & 0 & 5 & 2 & 91,00 \\ 0 & 0 & 0 & 0 & 0 & 3 & 1 & 3,13\end{array}$

Unidade Piqueri (LV) - Perfil 1031

$\begin{array}{rrrrrrrr}0 & 3 & t r & 0 & 0 & 37 & 0 & - \\ 0 & 0 & 2 & 0 & 0 & 2 & 3 & - \\ t x & 0 & 0 & 0 & 0 & 0 & 13 & -\end{array}$

Unidade Tanque (LH) - Perfil 1063

$\begin{array}{rrrrrrrr}0 & 1 & 0 & 0 & 0 & 14 & 0 & \text { - } \\ 0 & 0 & 2 r & 0 & 0 & 0 & 57 & 80\end{array}$


Tomou-se como critério para esses cälculos somente as percentagens dos minerais dos horizontes da par te do solo transportada, ou seja, acima da linha de seixos, quando existente (Quadro 1).

4.2.5 - MËDIA DE INTEMPERISMO COM BASE NA FRAÇÃO AREIA

A intensidade de intemperismo pode tambëm ser examinada usando-se a razão de intemperismo de minerais pesados (RIP) e dos leves (RIL). $\Lambda$ dos pesados é pela re lação zircão + turmalina sobre anfibōlios + piroxênios e que neste trabalho não se aplicou por não se ter encontrado os dois $\vec{u} 1$ timos mincrais nos solos estudados. A ra zão de intemperismo dos minerais leves (RIL) é dada pela relação quartzo sobre feldspatos, RUHE (1956), Quadro 3. 


\section{5 - RESULTAdOS E DISCUSSÃO}

Nesta parte serão apresentados os dados obtidos das anälises mineralögicas efetuadas nas frações argila e areia e discutido o comportamento e a distribuição dos minerais encontrados na topossequência estudada, face a distribuição dos solos na topografia e ao recobrimento da maioria das unidades de solo da área.

A parte alta da topossequência $\dot{\mathrm{e}}$ apresentada por três solos razos: um Litossolo substrato granito, um Podzólico com cascalho e um "Intergrade" entre Podzólico Verme 1ho Amare1o para Latossolo Vermelho Amarelo, respec tivamente as unidades Itapetinga, Rio Acima e Samambaia (Figura 3).

A anälise mineralögica da fração argila desses três solos mostrou o predomínio de minerais do grupo da caulinita seguidos pela gibbsita, material amorfo e pequenos teores de mica, vermiculita e montmorilonita (Qua dro 1). 
De todos os solos estudados neste trabalho os teores de caulinita da unidade Itapetinga foram os menores encontrados e com pequenas variações em profundidade. Por outro lado os valores de gibbsita foram os maiores. Segundo CATE (1960) o acümulo de gibbsita no solo geralmente tem sido considerada como uma indicação de um estâa gio avançado de alteração. Contudo, o elevado teor de gib sita de solos em tais condições pode ser explicado com base nos trabalhos de MCCRAKEN et a1.. (1971). Esses autores estudaram solos da Carolina do Norte, particularmente as séries Cecil e Haysville e que são exemplos de Podzólico Vermelho Amarelo. A série Haysville ê. de topo de montanha e é solo razo (a exemplo da unidade Itapetin ga deste trabalho) apresentando uma variação de 16 a $46 \%$ de gibbsita. Sabe-se que para a formação de altos teores de gibbsita as condições ideais são: boa drenagem com uma contínua e râpida renovação das soluções percolantes, um meio bastante pobre em bases, clima quante e úmido, rocha rica em plagioclāsio câlcico e posição topográfica eleva da. Parece que essas condições se verificam nas regiões dos solos das partes altas tratados neste trabalho.

MCCRAKEN et a1., (1971), explicam que altos teo res de gibbsita em solos de regiões altas ocorre quando hă uma räpida percolação de grande quantidade de ägua in filtrando rapidamente o solo, removendo a silica e as ba ses, como resultado do intemperismo. A concentração de sílica sendo menor que $1 \mathrm{ppm}$, resulta na formação de gib bsita,que é a forma estảvel. 
O baixo grau de alteração dos solos da unidade Itapetinga, como tambêm das unidades Rio Acima e Samambaia é comprovado pelos baixos valores de intemperismo médio (Quadro 1) calculados segundo JACKSON \& SHERMAN (1953). Este resultado, esta de acordo com o conceito de catena proposto por MILNE (RUHE, 1960), o qual estabelece que os solos situados nas partes altas são mais jovens do que os de encosta e estes mais jovens que os de sopé.

0 teor de amorfo (Quadro 1) desses três solos (região alta da topossequência), varia pouco de acordo com a profundidade. Em virtude desses materiais exibirem elevada superfície específica associada a alta capacidade de troca catiônica, exercem uma grande influência na química do solo, justificando por conseguinte os trabathos envolvidos em sua determinação. O material amorfo foi determinado por dois métodos: o de HASHIMOTO \& JACKSON (1960), Quadro 1, e o de FIELDS \& PERROTT (1966); este ûltimo método presta-se para testes rảpidos de campo, todavia limitado ao teor máximo de 7 : de material amorfo (Quadro 2). Nos casos possíveis de comparação (teores de material amorfo abaixo de $7 \%$ ), pode-se observar que tais teores, encontrados nelo primeiro método, são maiores que os teores encontrados pelo segundo, embora a determi nação feita segundo HASHIMOTO \& JACKSON (1960) tenha sido feita na fração argila e a do segundo método na fração menor que $2 \mathrm{~mm}$, englobando portanto as frações argi1a, limo e areia. Assim no caso dos solos da parte alta da topossequência pode-se afirmar que hâ mais de $7 \stackrel{0}{\text { de }}$ 
amorfo nas unidades Itapetinga e Rio Acima, como no hor zonte B21 da unidade Samambaia, não se podendo precisar contudo, o teor mäximo de amorfo acima daquele teor.

o teor de mica da fração argila, mineral este provavelmente de origem primäria, diminui em superfície no 1itossolo, ocorrendo o inverso na unidade Rio Acima (Quadro 1). Variações mais acentuadas do teor de mica que essas duas unidades foram constatadas em Litossolos e Podzólico Vermelho Amarelo, variação Piracicaba, ESCOBAR et a1., (1973).

A diminuição do teor de mica em superfície de solos foi explicada por JACKSON et a1., (1948) que estabeleceram a sequência de intemperismo para minerais com diâmetro equivalente esférico inferior a 2 micra. Segun do tais autores a intensidade de intemperismo diminui com a profundidade do solo.

Os teores mais elevados de mica encontrados na unidade Samambia deve-se a natureza do material de origem do solo, um micaxisto.

Minerais do tipo $2: 1$, de origem secundäria como vermiculita e montmorilonita, ocorrem em teores muito ba xos não sö nesses solos das regiões altas, como em todos os demais da topossequência. Isto se deve ao fato desses solos terem se desenvolvido em clima tropical e com boa drenagem. 
$\mathrm{Na}$ anảlise mineralógica da fração areịa das três primeiras unidades de solo da topossequência verifi cou-se que os feldspatos são predominantes no Litossolo, cedendo seu lugar para o quartzo no Podzólico com cascatho, desaparecendo por completo na unidade Samambia(Qua dro 3). Com os dados de quartzo e feldspatos desse quadro construiram-se os valores da razão de intemperismo dos minerais leves (RIL) segundo RUH!E (1956). Não aparecem neste quadro os valores da RIL dos perfis 1032,1052, 1031 e 1063 por não se ter encontrado feldspatos em mais de um horizonte de tais solos. Também não se efetuou a relação dos minerais pesados por não existir anfibólios e piroxênios necessârios para se estudar tal relação.

A RIL do horizonte A1 da unidade Itapetinga ë 0.72 ; do horizonte $B / C$ é 0,39 e do horizonte $C$ é 0,48 (Quadro 3). Quando os quocientes dos horizontes A e B são maiores do que o do $C$ significa que hả um acủmulo residual de minerais menos resistentes, isto é, A e B são formados a partir de C, RUHE (1969). Significa tambẻm que o intemperismo decresce de acordo com a profundidade. Notou-se uma inversão nos valores da RIL dos horizontes dessa unidade que julgou-se não merecer discussão por se tratar de diferenças entre valores muito pequenos.

Os solos da unidade Rio Acima, apresentam uma distribuição regular de todos os minerais encontrados, quer na fração argila, quer na fração areia, não se notando evidência de recobrimento. o que está de acordo com as observações de campo. Essa afirmação se verifica 
ao se notar que a RIL dos horizontes A e B são maiores do que os de C (Quadro 3).

$\mathrm{Na}$ unidade Samambaia jả com suas vertentes mais suaves começam a surgir evidências de recobrimento na to possequência tanto pelas observações de campo como pelo aumento brusco de mica da fração areia no horizonte IIC3 (Quadro 3).

Os difratogramas da fração argila do Litossolo (Perfil 1011), do Podzólico com cascalho (Perfil 1037) e do "Intergrade" (Perfil 1032) se encontram respectivamen te nas Figuras 8,9 e 10. Indicam a presença de caulinita, gibbsita e mica. Ocorre ainda na amostra glicolada (Figura 8) um espaçamento a $14 R$ indicando a presença de um mineral 2:1 identificado como vermiculita. A mesma amostra aquecida a $350^{\circ} \mathrm{C}$ apresenta em seu difratograma a contração do espaçamento de $14 \AA$ o qual se confundiu com o de mica. No tratamento a $550^{\circ} \mathrm{C}$ ainda na Figura 8 , pode-se observar o desaparecimento dos espaçamentos da cau. linita, permanecendo apenas o da mica.

Os termogramas da fração desses três perfis (Li tossolo, Podzólico com cascalho e "Intergrade") mostram os picos endotérmicos da gibbsita e caulinita(Figuras 11 , 12 e 13) seus principais componentes.

$\Lambda$ parte intermediäria da topossequência estudada estâ representada por cinco perfis de solos pertencen tes ao grande grupo Podzólico Vermelho Amarelo orto(PV). 


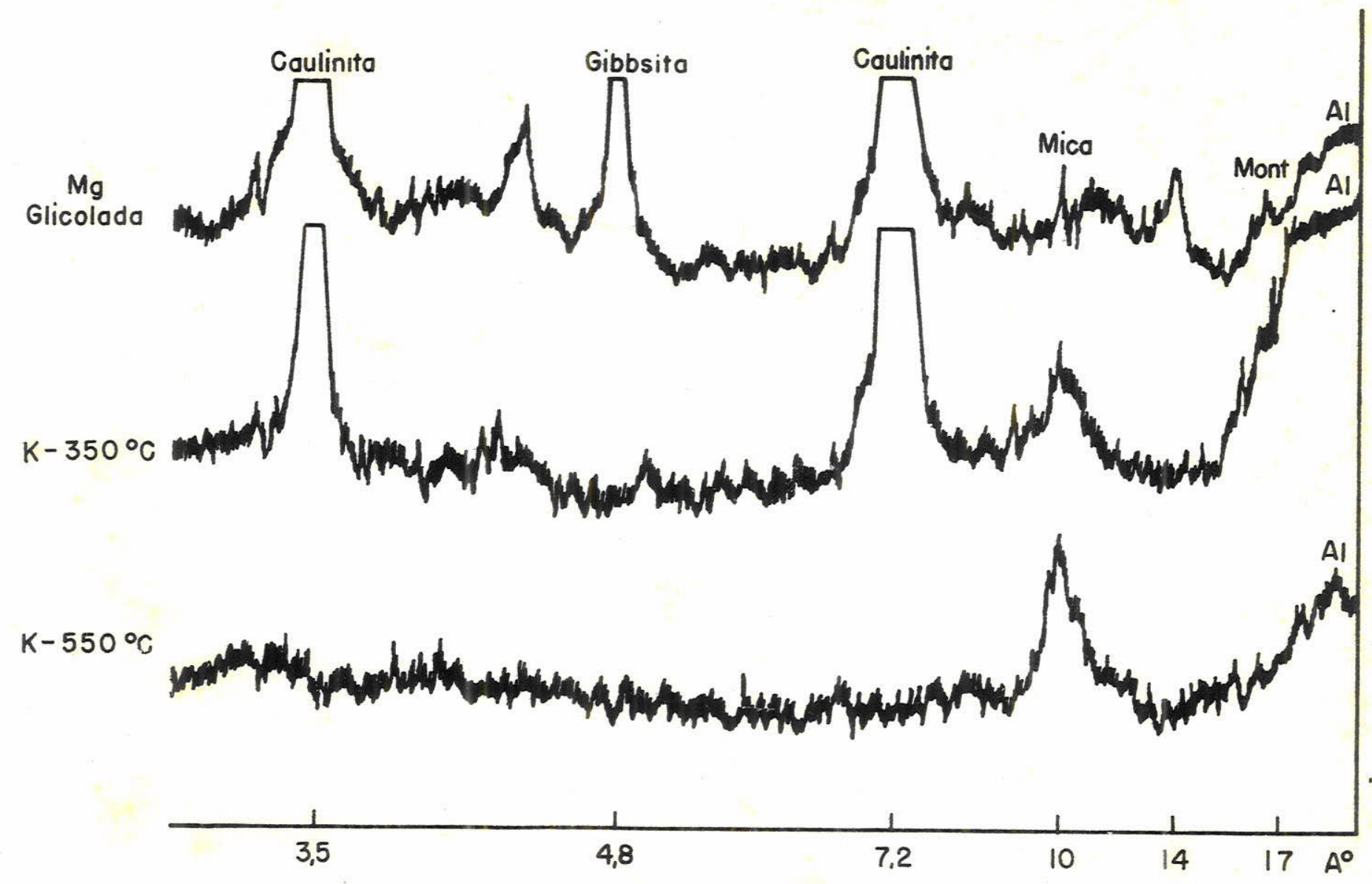

Figura 8 - Difratogramas da fração argila de amostras orientadas da unida de Itapetinga, perfil 1011 


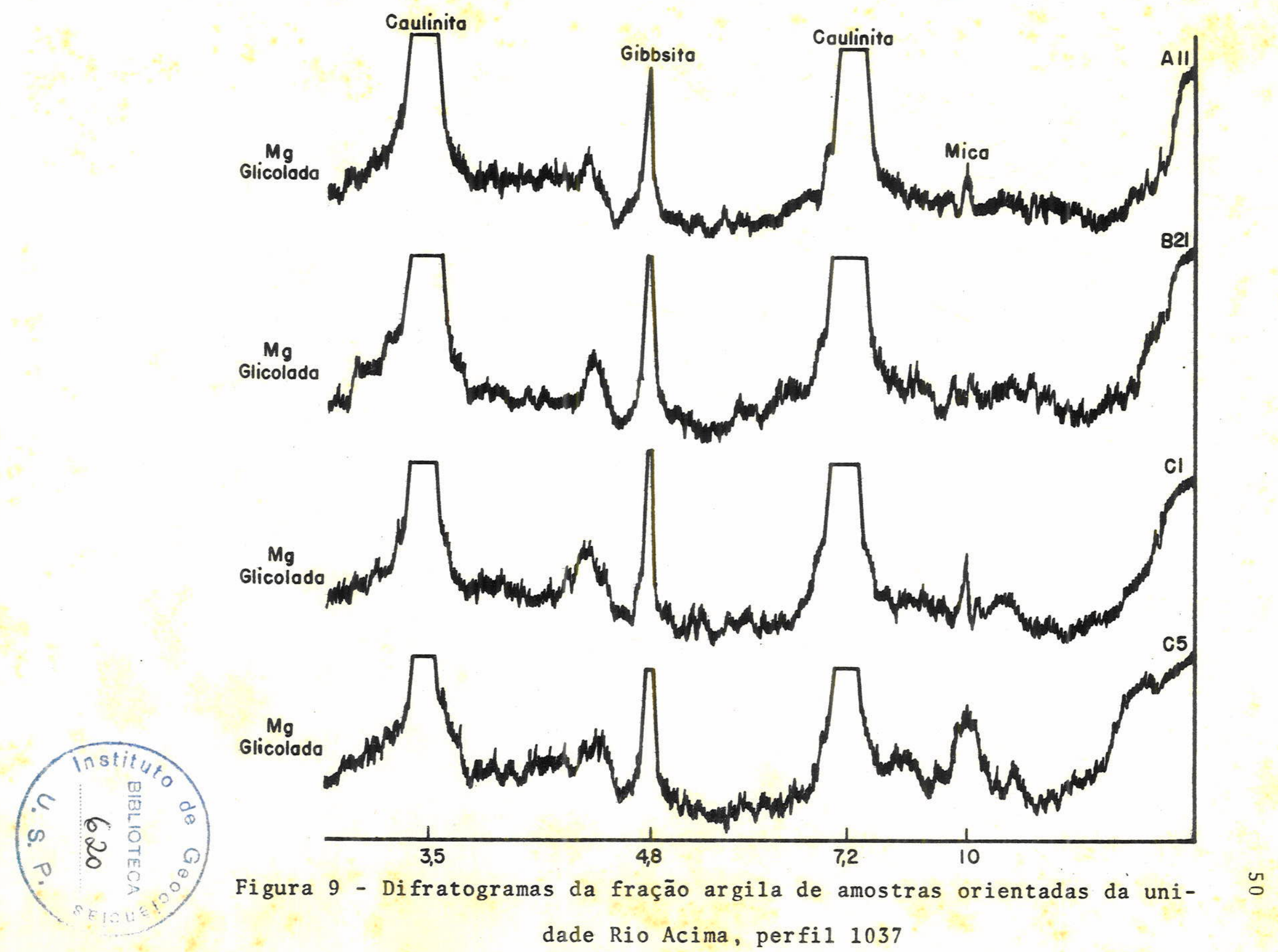




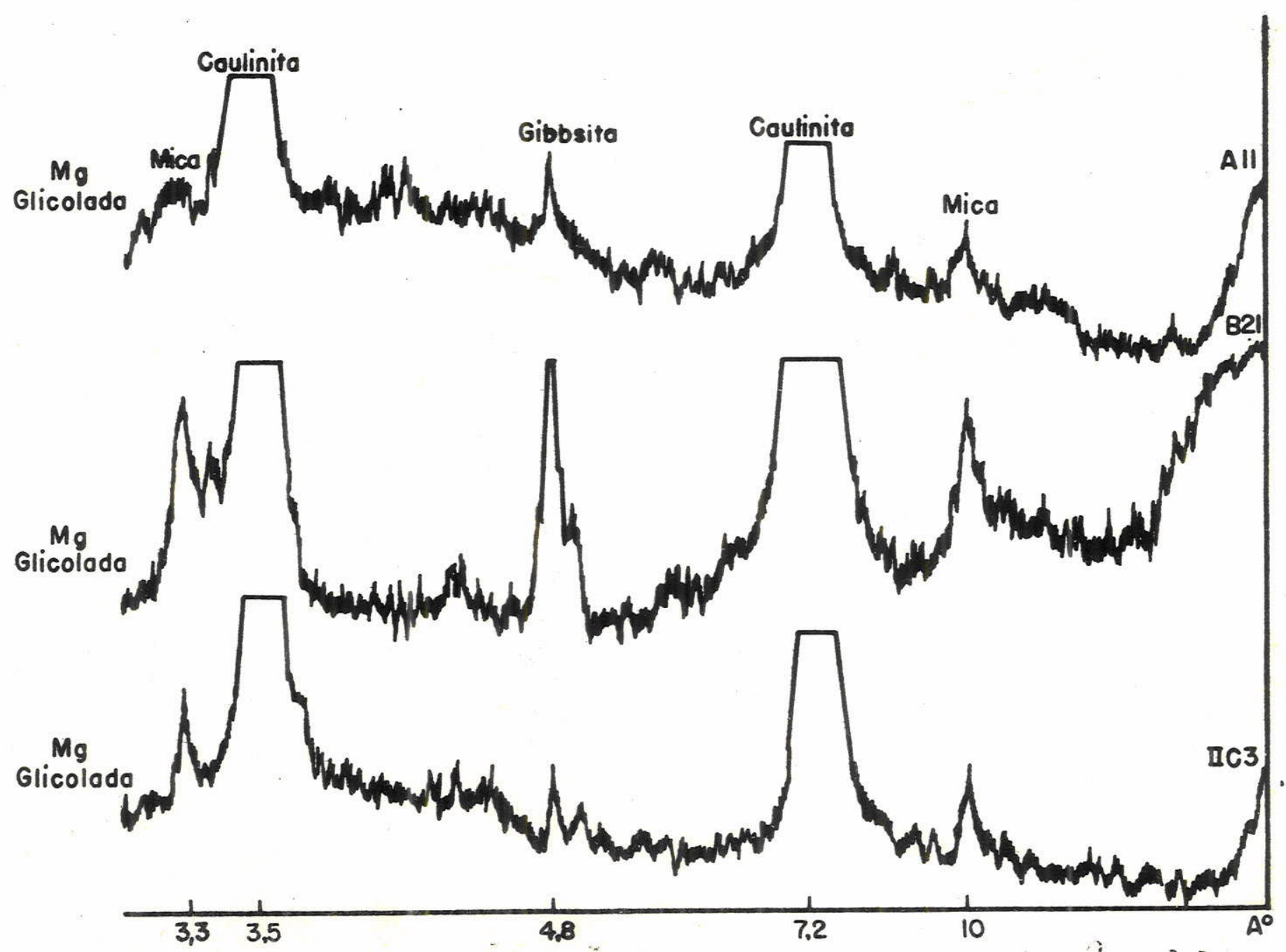

Figura 10 - Difratogramas da fração argila de amostras orientadas da uni dade Samambaia, perfil 1032 


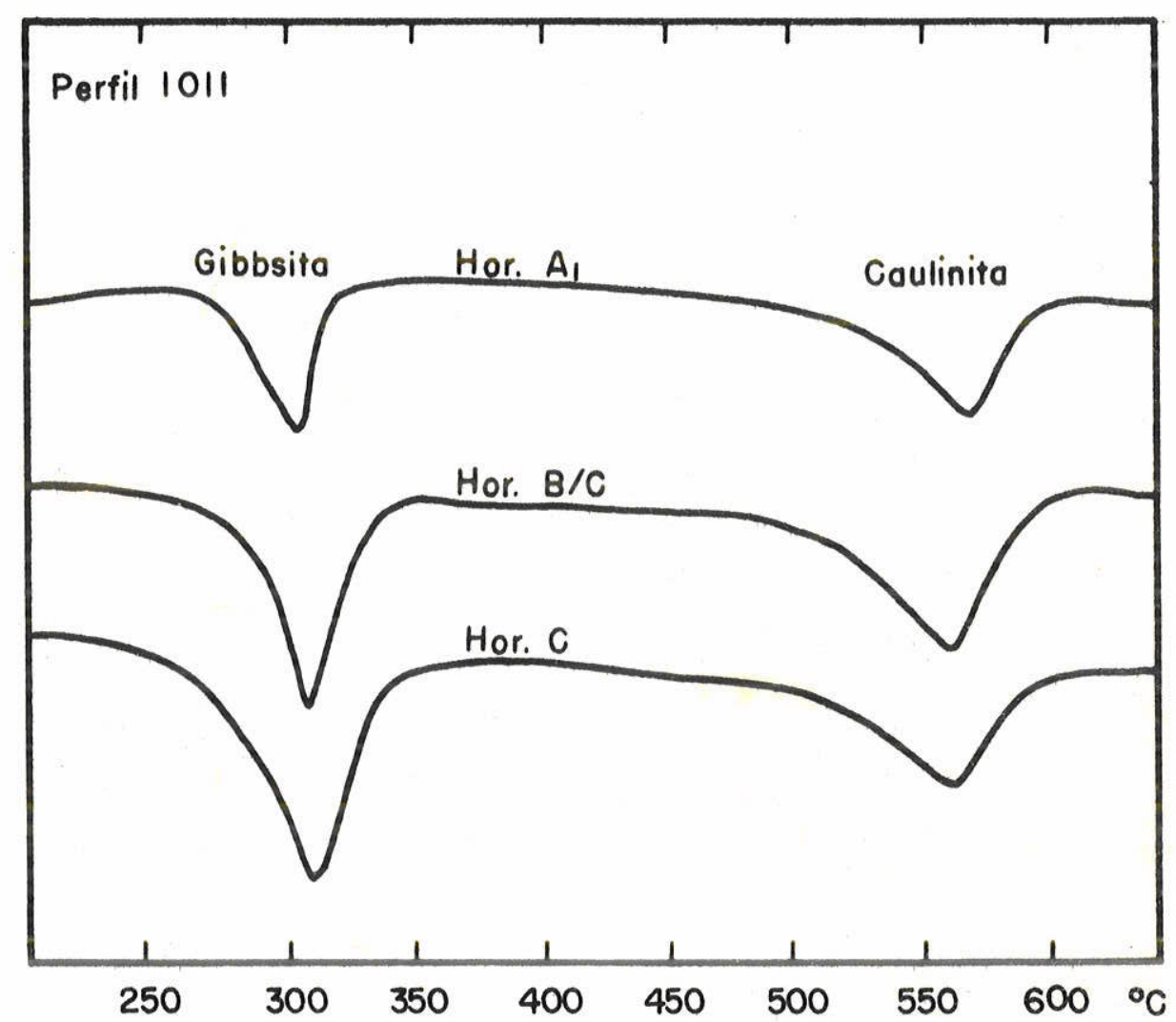

Figura 11 - Termogramas da fração argila da unidade Itapetinga 


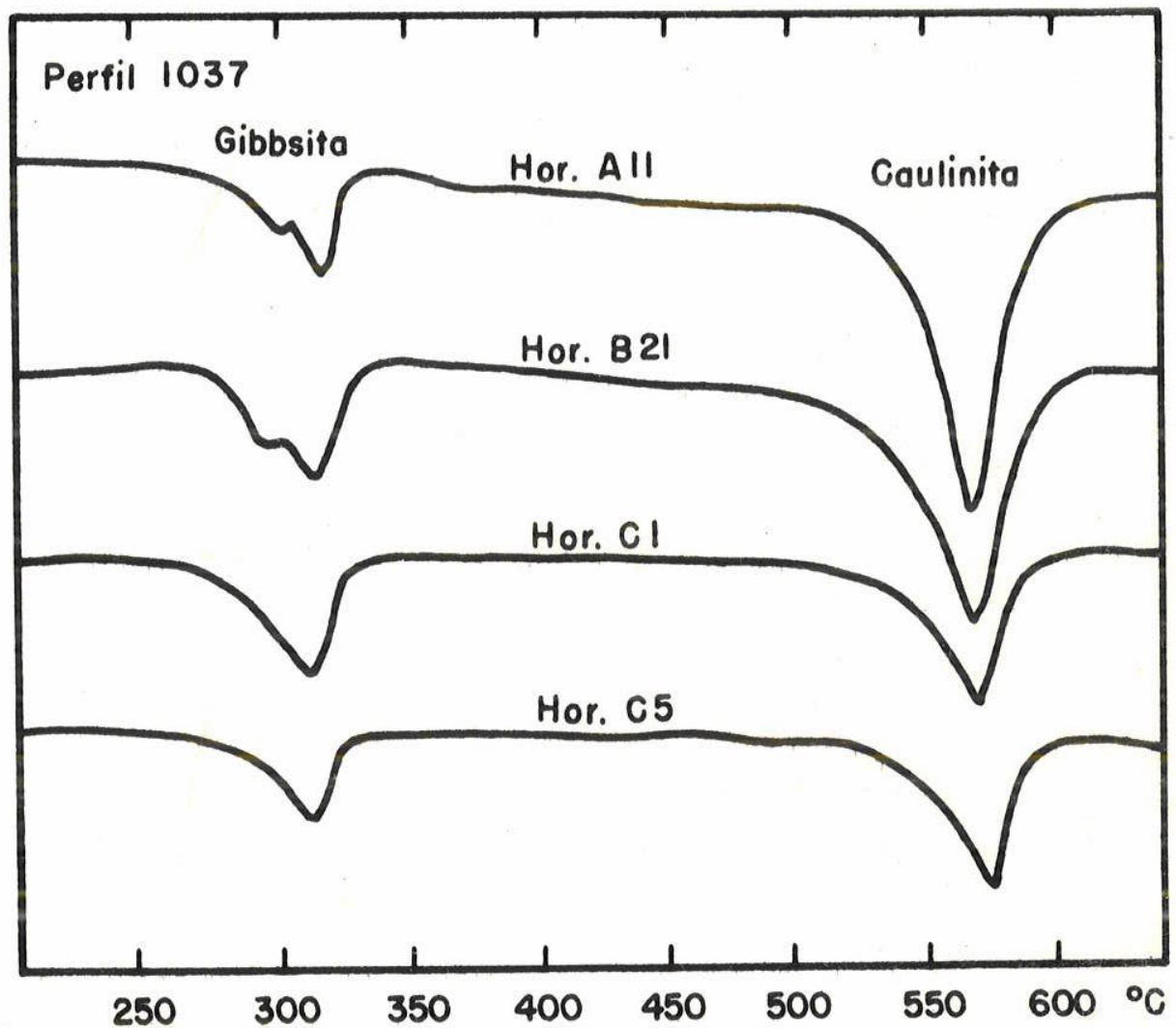

Figura 12 - Termogramas da fração argila da unidade Rio Acima 


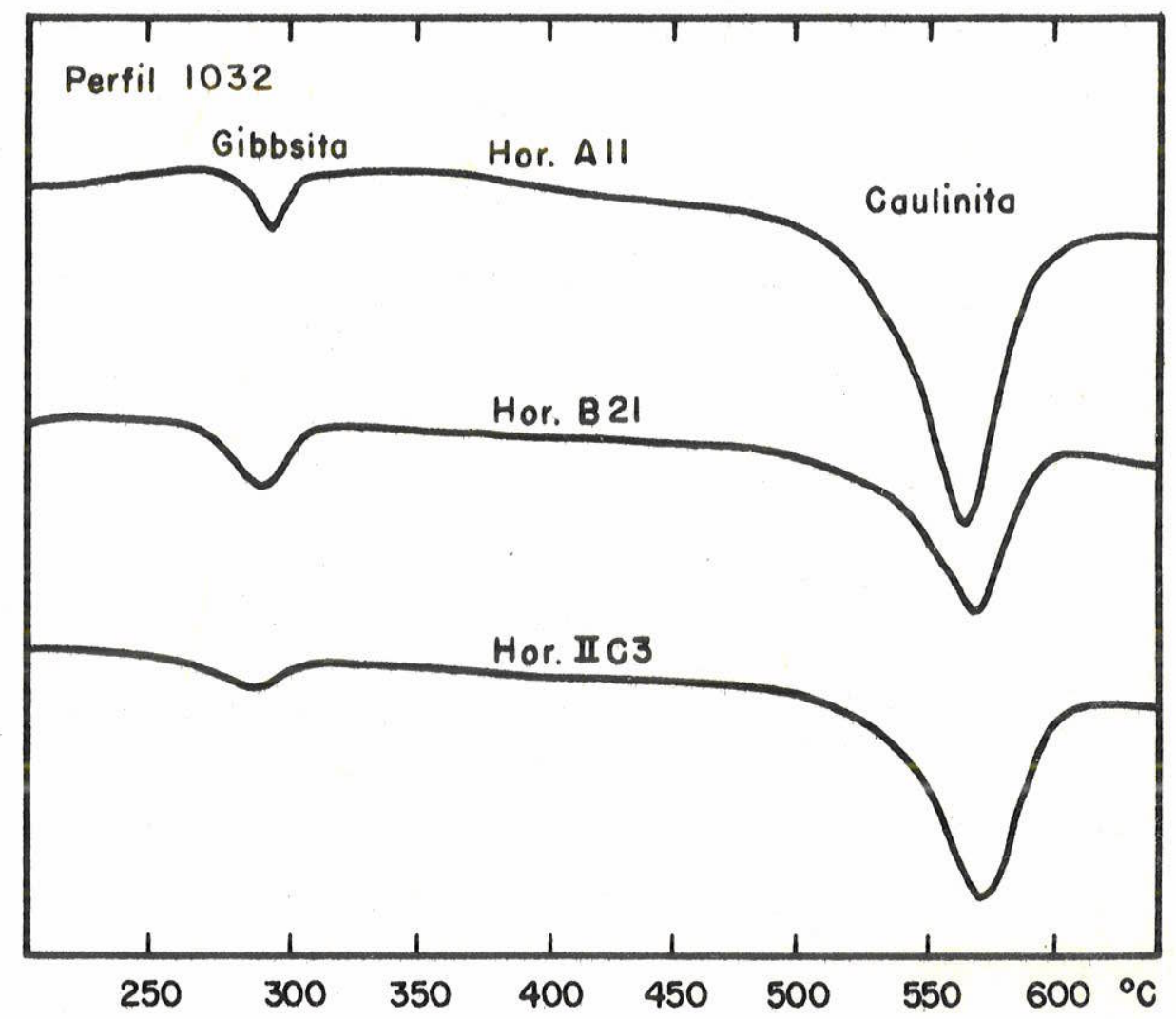

Figura 13 - Termogramas da fração argila da unidade Samambaia 
Compreende as unidade Rosärio, Cachoeira e Caetetuba(Qua dro 1) respectivamente solos 3,4 e 5 da Figura 3 .

Os solos situam-se na meia encosta, com declives menos acentuados que os das partes altas, mais profundos que esses e caracterizados por recobrimento conforme descrição no campo. Isto se deve provavelmente à semelhança dos componentes dos dois materiais que formam os solos da parte intermediária da topossequência em estudo.

A mineralogia da fração argila dos solos PV, apresenta va riações pouco significativas. Nas três unidades nota-se o predomínio de caulinita, seguido de material amorfo (Quadro 1). Os teores de gibbsita desses solos são os mais baixos da topossequência não u1trapassando $10 \%$, evidenciando um grau de intemperismo menor e fraca lixiviação. Por outro lado, o Perfil 1052 da unidade Caetetuba, pelos dados quantitativos obtidos (Quadro 1) apresentou os maiores teores de montmotilonita, talvez devido a con dições de lixiviação fraca.

Os difratogramas da fração argila dos diferentes horizontes desses solos mostram a presença de seus principais componentes (Figuras 14 a 18). Nos termogramas das mesmas amostras aparecem gibbsita e caulinita(F guras 19 a 23).

Constatou-se, pelos dados obtidos de intemperis mo médio, que os solos das unidades em questão (unidades 


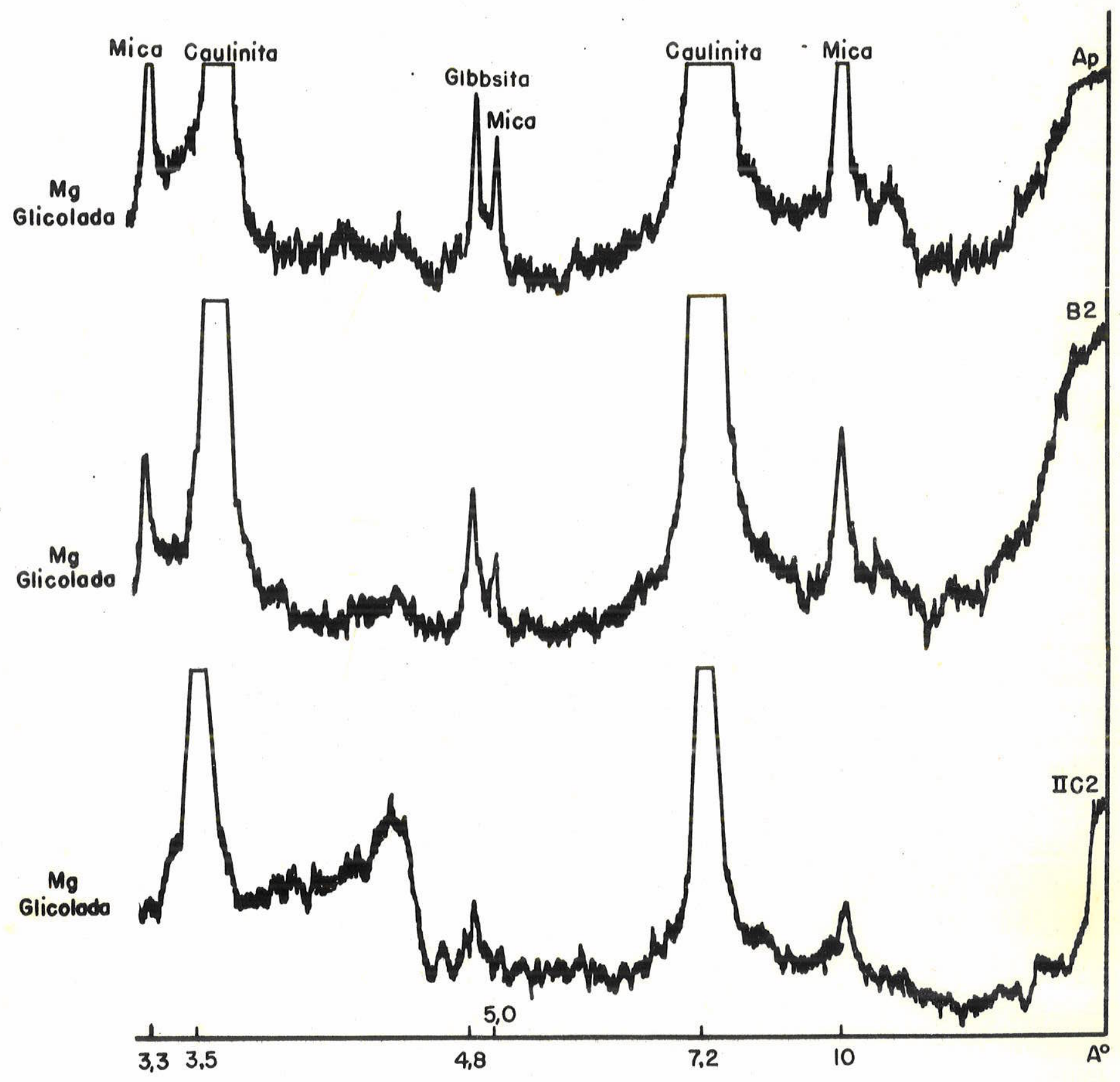

Figura 14 - Difratogramas da fração argila de amostras orientadas da unidade Rosärio, perfil 1055 


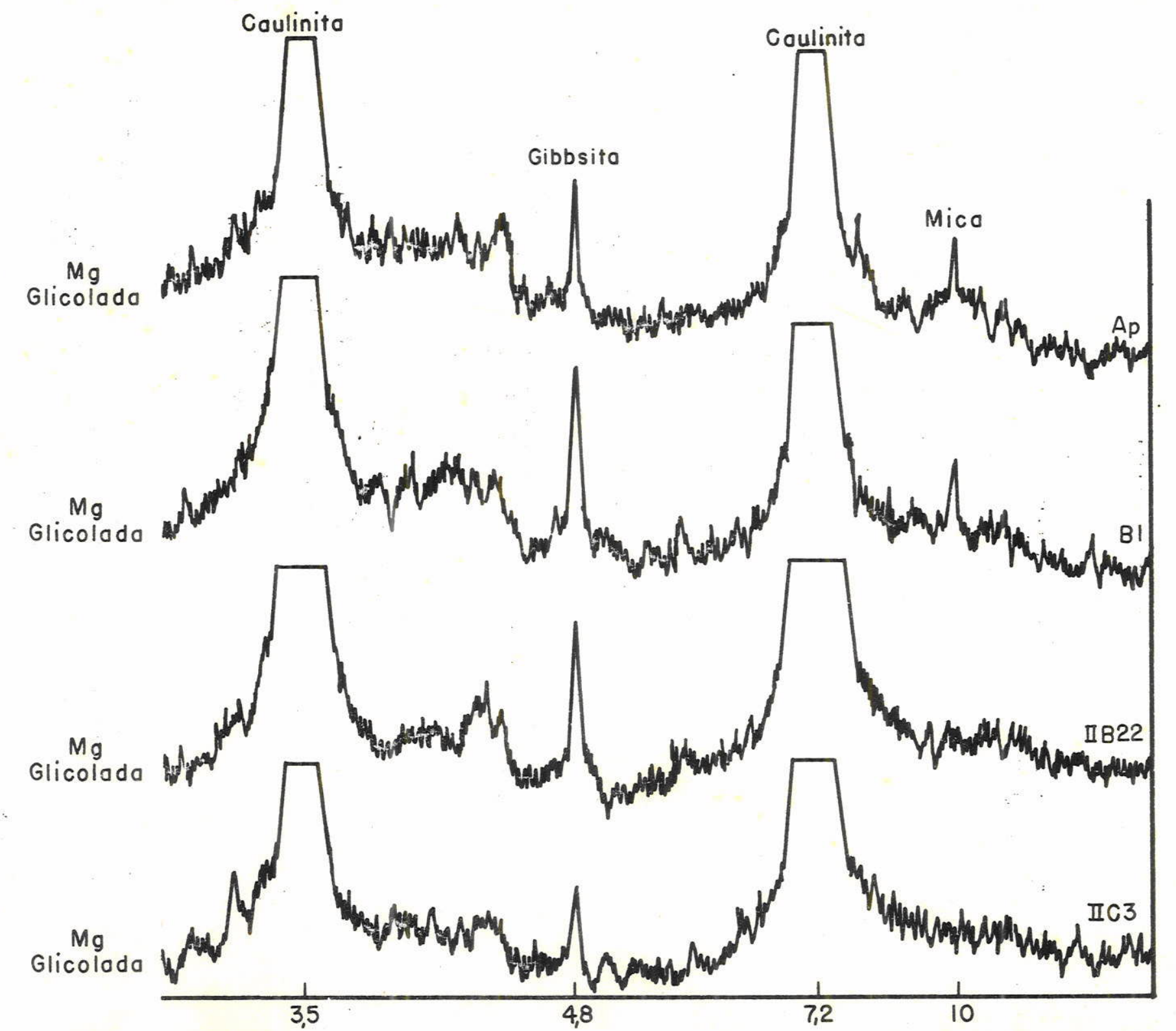

Figura 15 - Difratogramas da fração argila de amostras orientadas da unidade Cachoeira, perfil 1034 


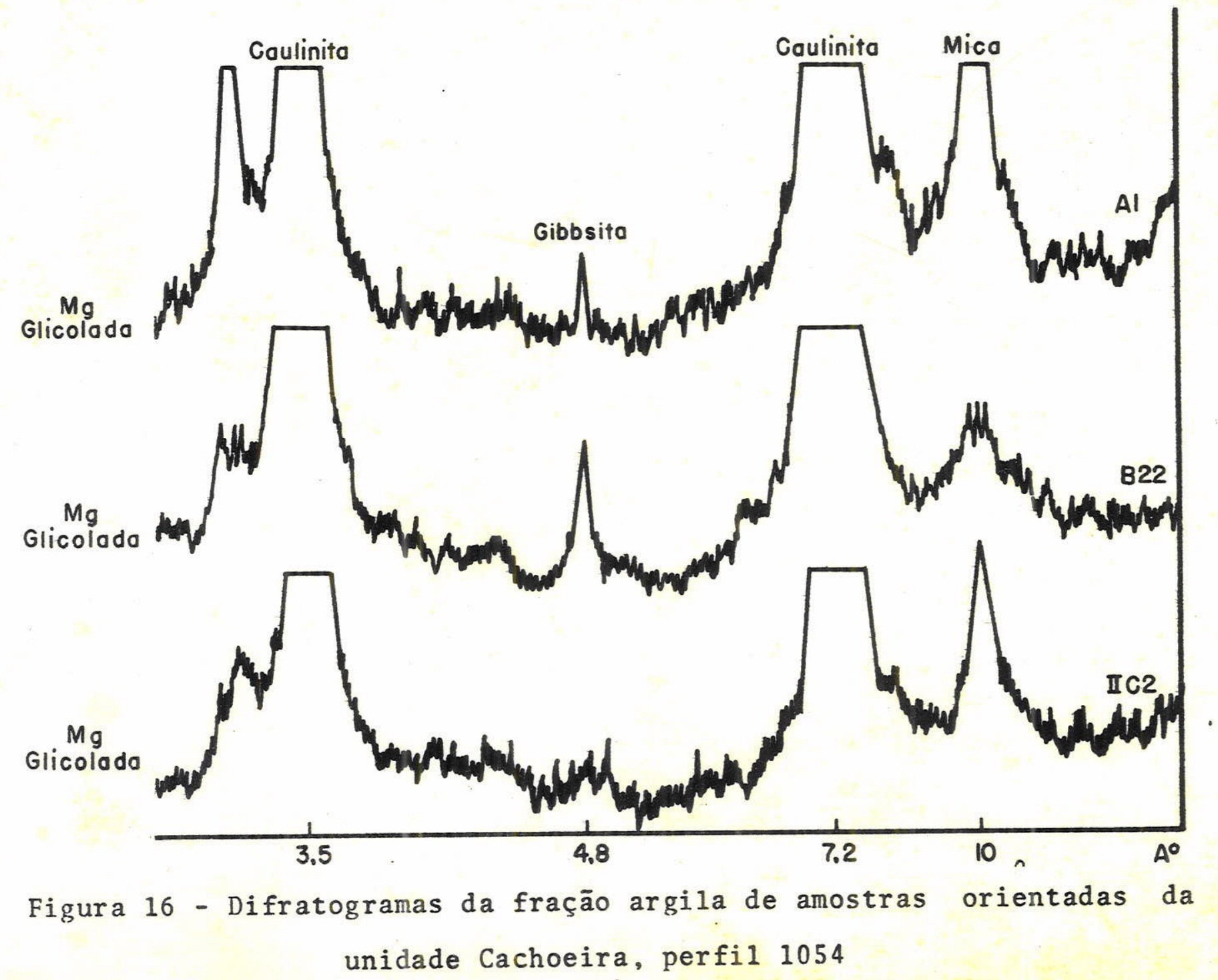




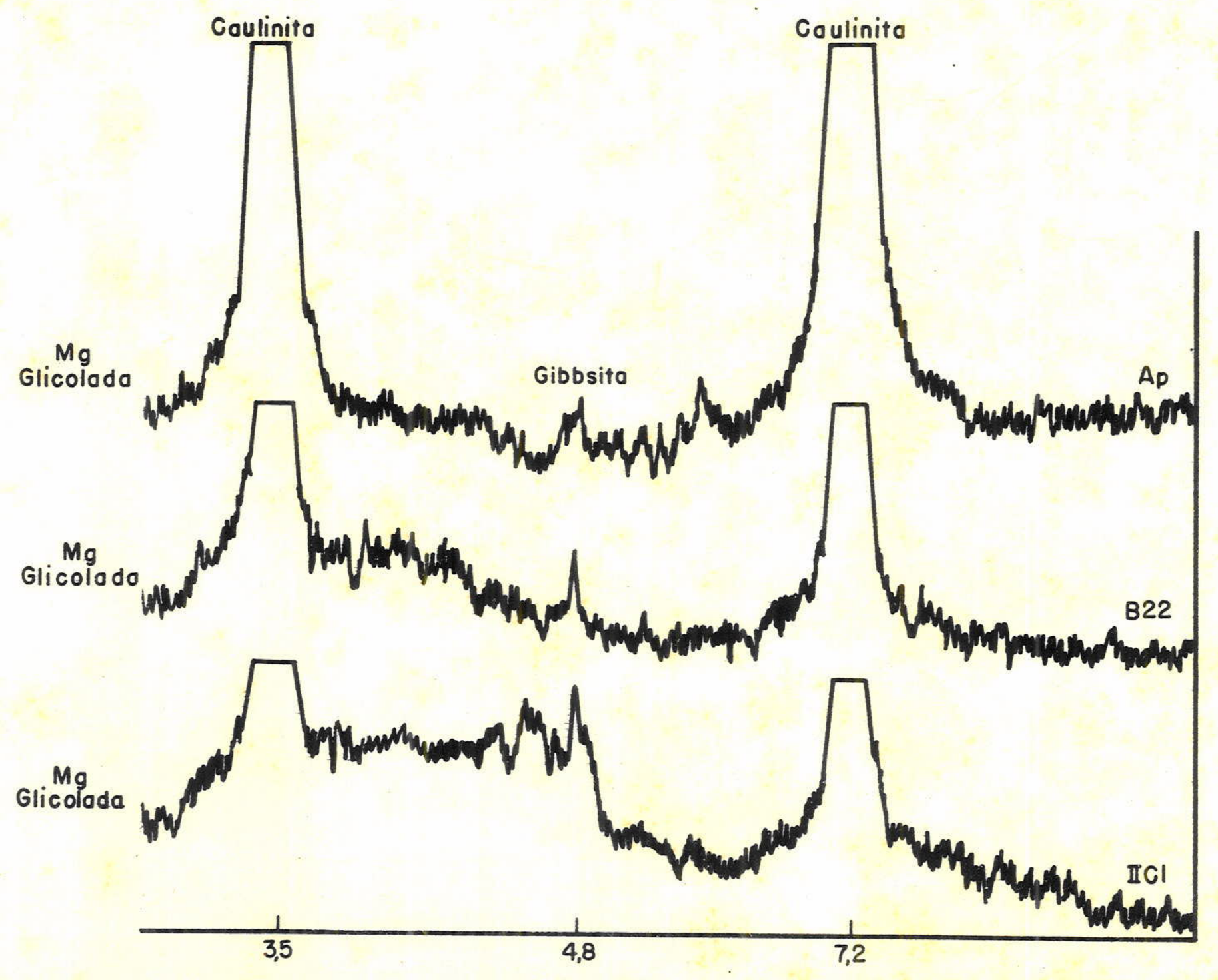

Figura 17 - Difratogramas da fração argila de amostras orientadas da

unidade Caetetuba, perfil 1064 


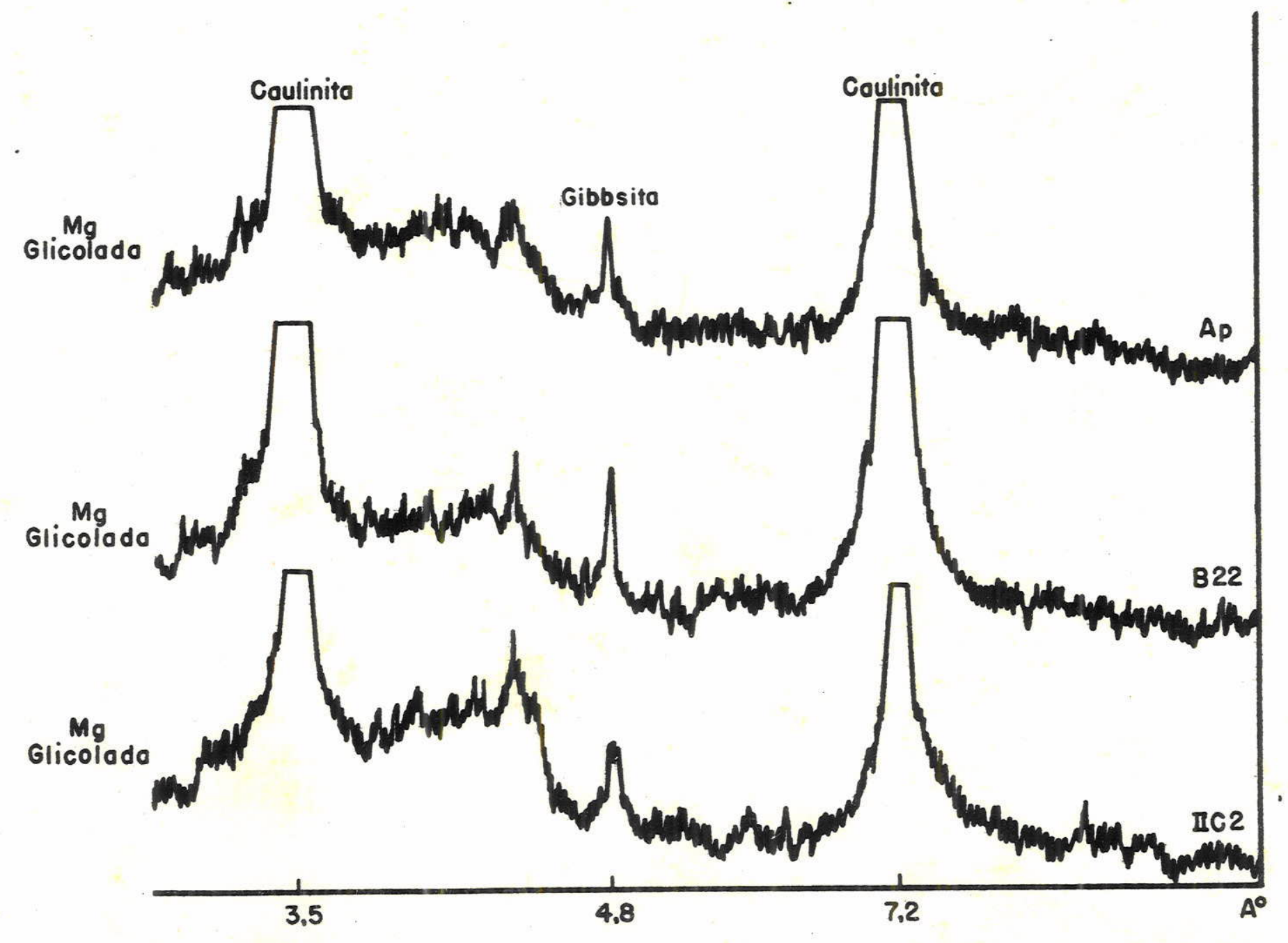

Figura 18 - Difratogramas da fração argila de amostras orientadas da unidade Caetetuba, perfil 1052 


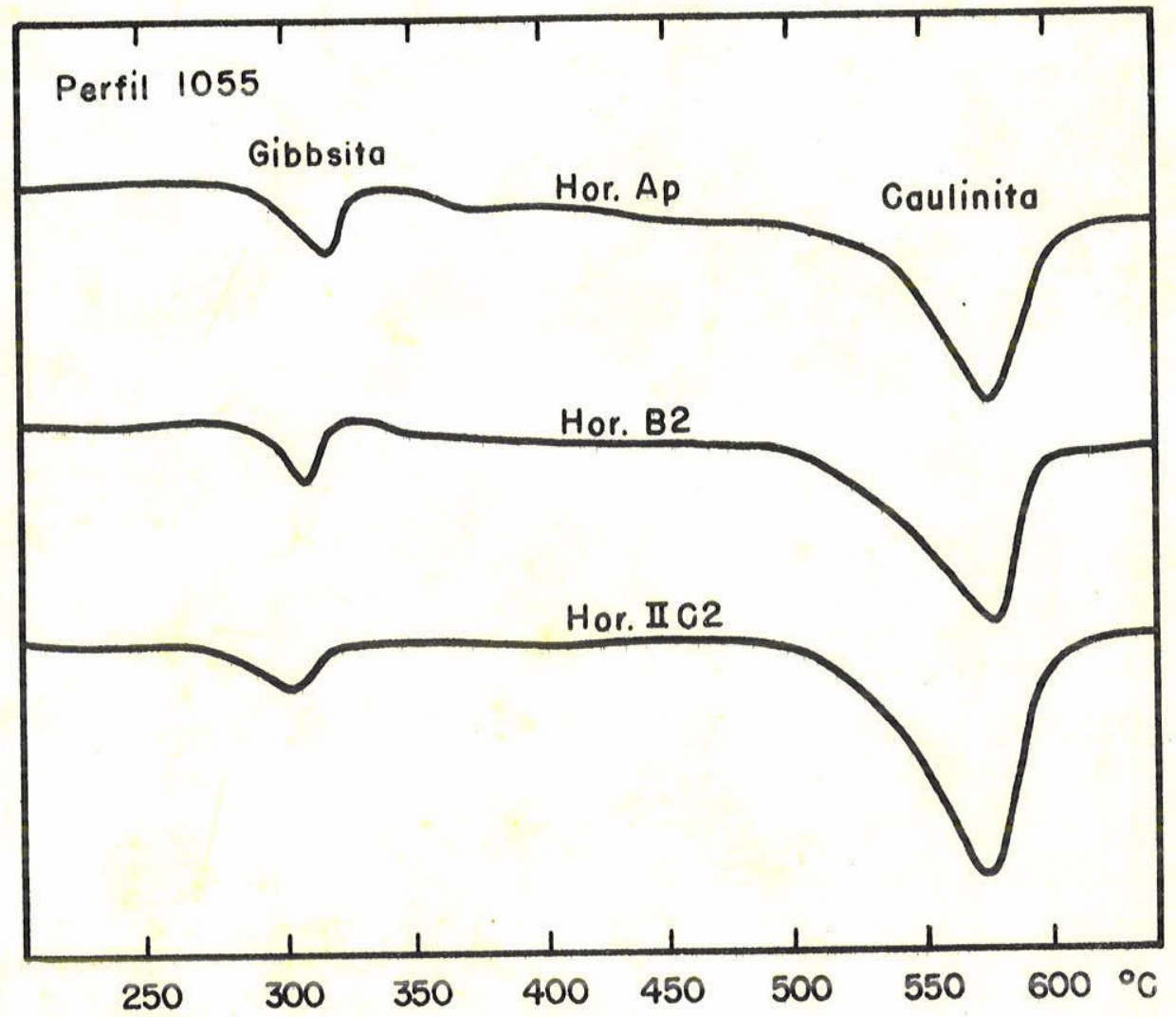

Figura 19 - Termogramas da fração argila da unidade Rosärio 


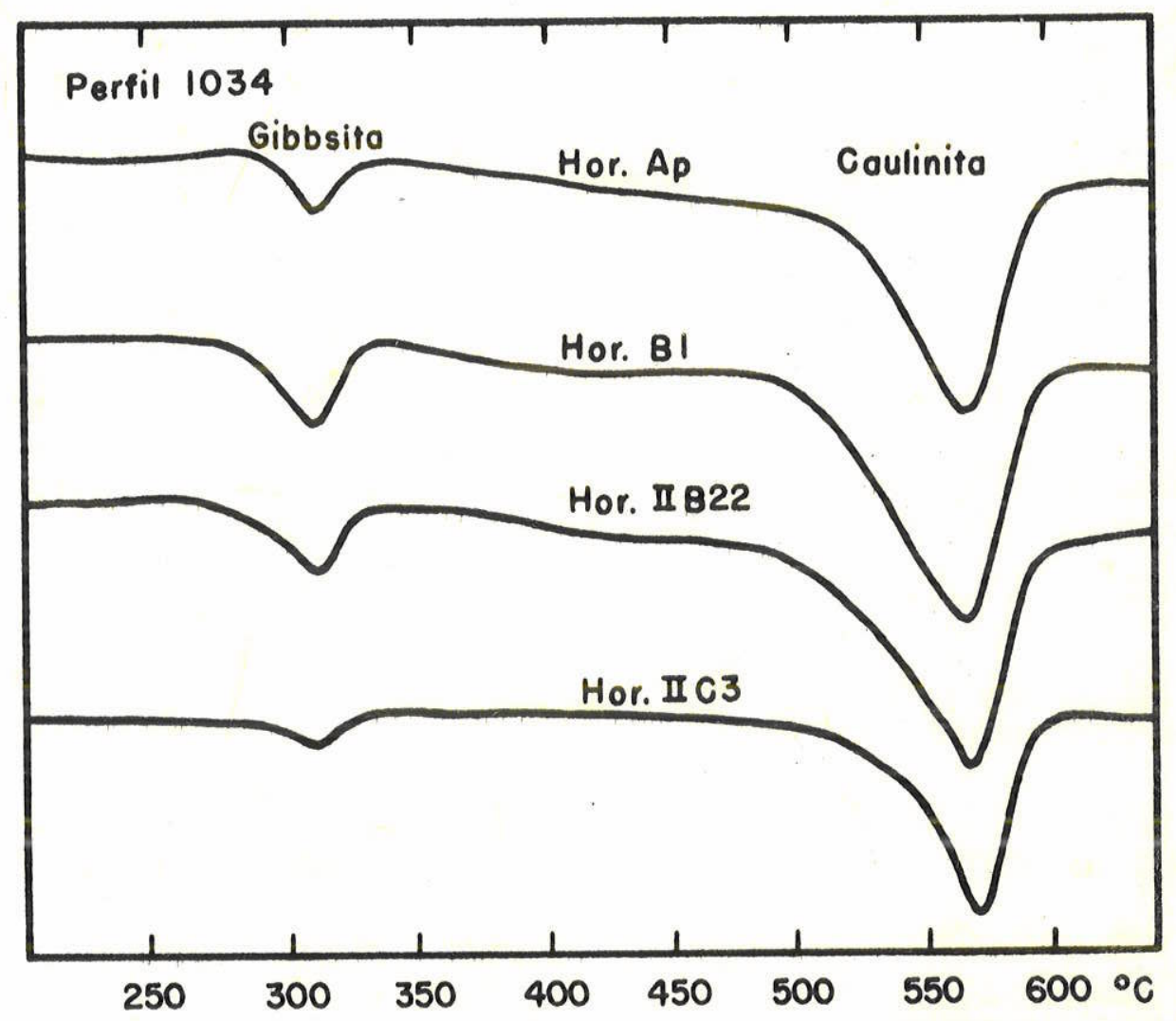

Figura 20 - Termogramas da fração argila da unidade Cachoeira, perfil 1034 


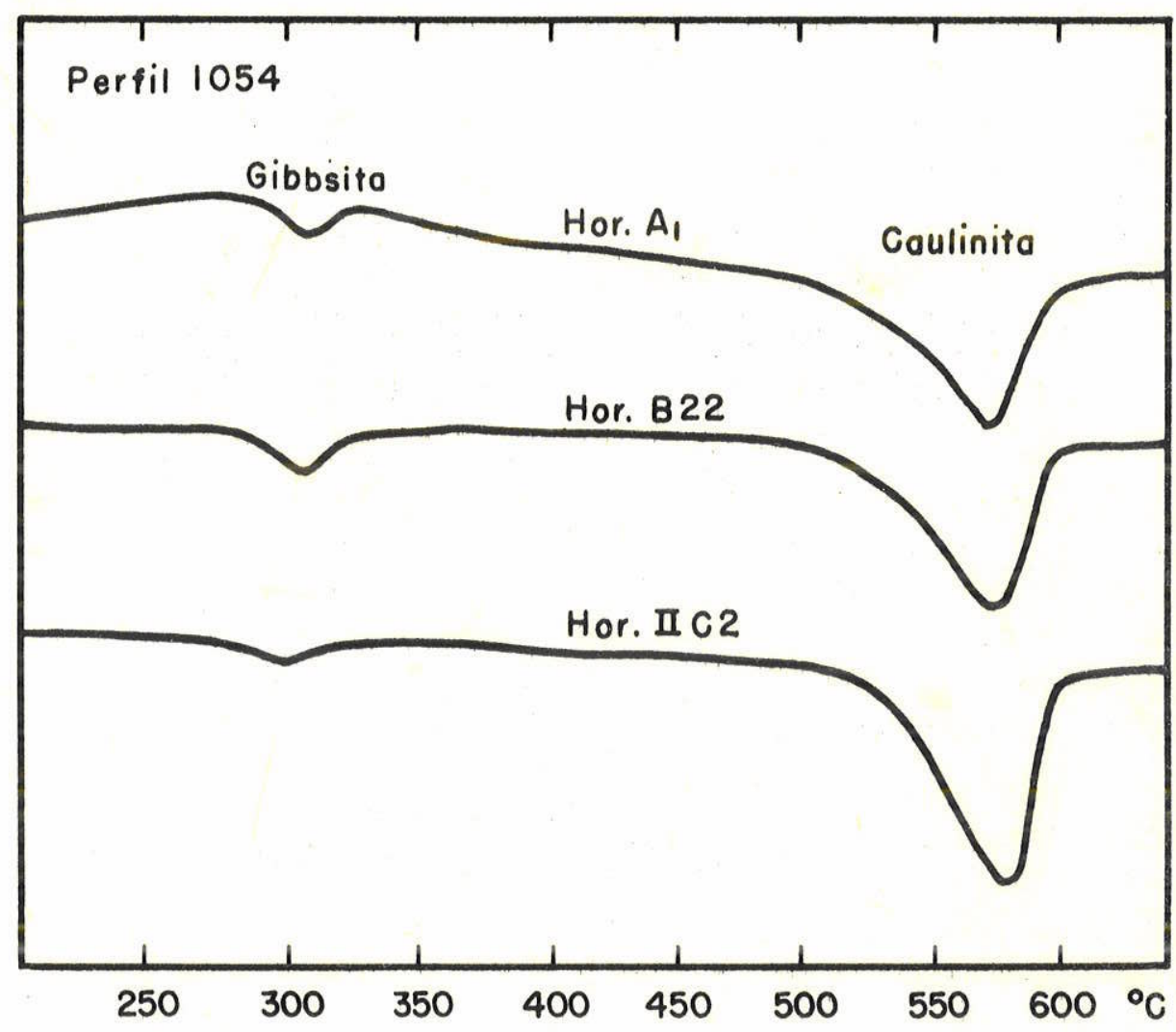

Figura 21 - Termogramas da fração argila da unidade Cachoeira, perfil 1054 


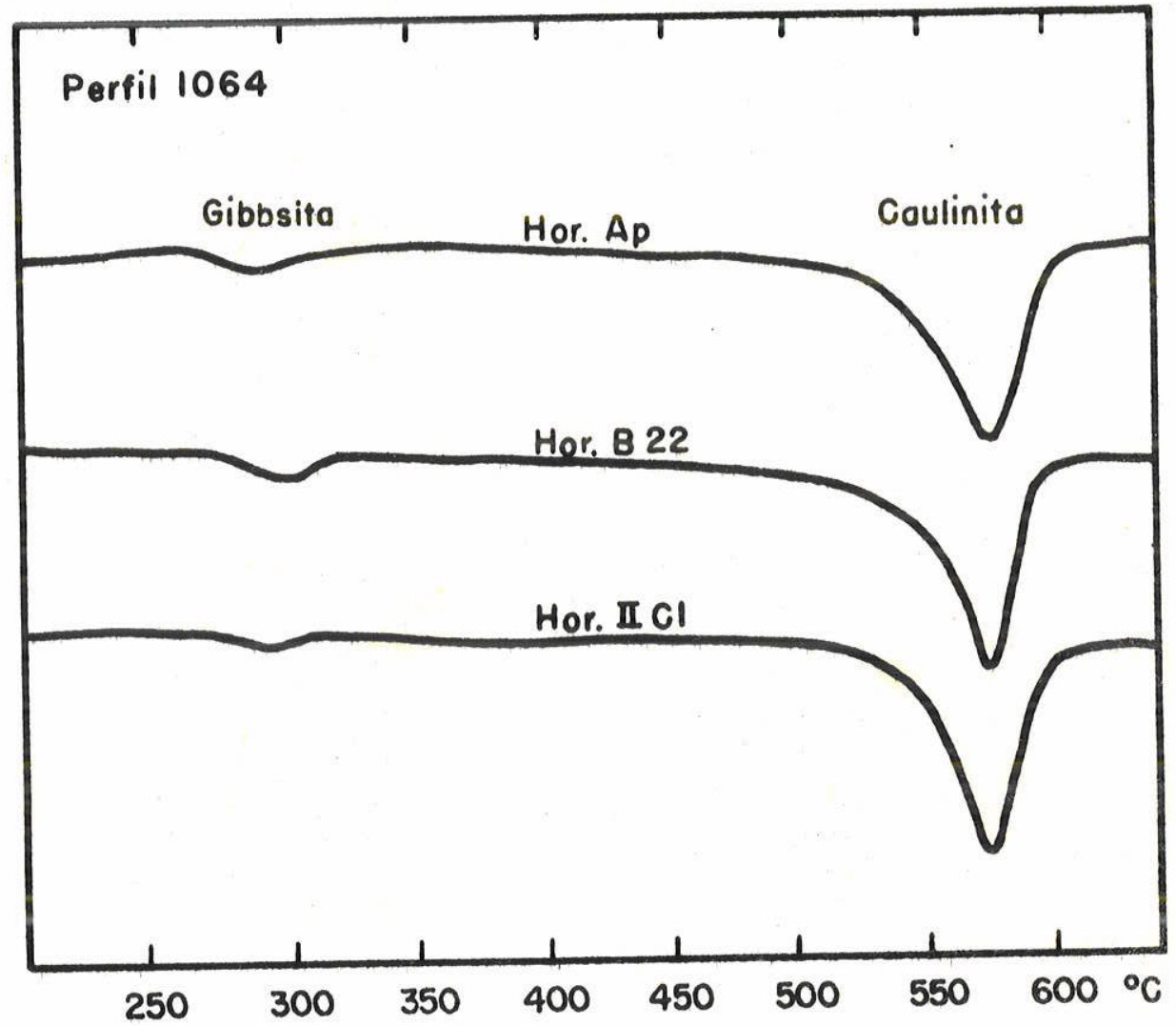

Figura 22 - Termogramas da fração argila da unidade Caetetuba, perfil 1064 


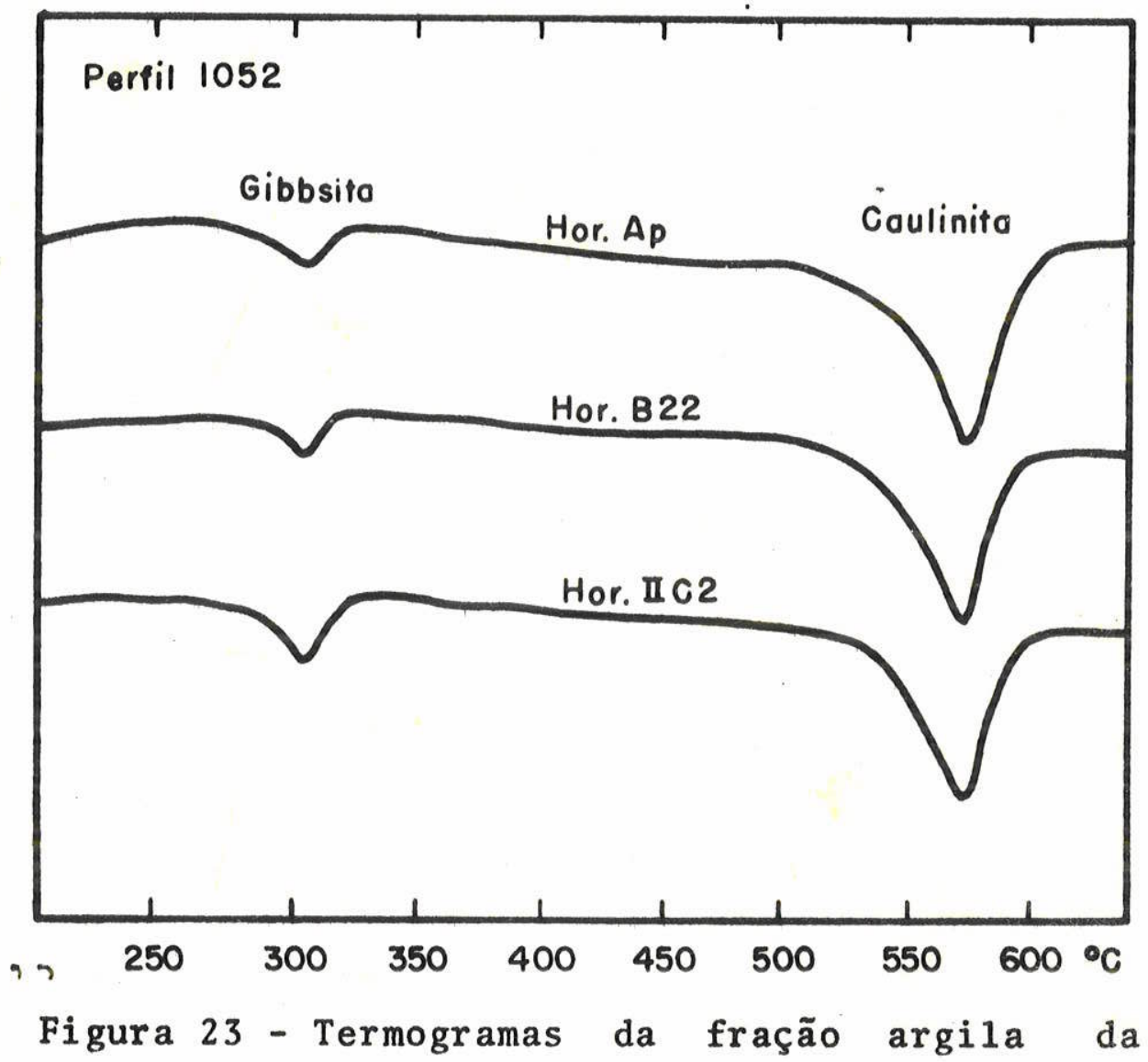
unidade Caetetuba, perfil 1052 
Rosärio, Cachoeira e Caetetuba) são mais intemperizados que os solos das äreas mais altas. Apresentam valores de intemperismo mëdio, entre 3,1 e 4,2 , superiores aos dos três perfis de solo da parte alta da topossequência, indicando um estâdio de intemperismo mais avançado.

A mineralogia da fração areia dos perfis dos Podzólicos da parte média da topossequência, mostram uma acentuada diminuição nos teores de ortoclảsio e o desapa recimento dos plagioclásios, em relação aos dois primeiros perfis da parte alta da topossequência (Quadro 3).

Essas diferenças mineralögicas entre os horizon tes, podem ter surgido por processos pedogenéticos poste riores a deposição do material, jä durante a formação do solo, no local em que se encontra atualmente.

Os dados da RIL se apresentam diversificados, im possibilitando qualquer tentativa no sentido de mostrar a aplicação desses dados para confirmar os casos de reco brimento.

A descontinuidade litológica observada pela pre sença do recobrimento poude ser detectada pela variação de teores de quartzo e mica da fração areia. Nos horizon tes abaixo do recobrimento hả um decréscimo considerävel do teor de quartzo e um aumento do teor de mica em rela ção aos horizontes do material do recobrimento. No entre tanto na relação $0 z / F e l d s$ não se evidenciou a descontinuidade 1itológica observada no campo. 
A parte final da topossequência estudada è representada por três perfis em latossolo e são os solos números 6 e 7 (Figura 3), caracterizados por recobrimen to de acordo com as observações de campo. Estão localiza dos nas partes mais baixas, junto às calhas dos principais cursos d'água e são mais profundos que os Podzólicos. Predominam nesses solos, caulinita, gibbsita e amor fo, sendo que os teores de gibbsita são superiores aos dos perfis da parte intermediäria da topossequência. A caulinita apresenta um teor elevado (em detrimento da gibbsita) no horizonte $\mathrm{C}$ da unidade Piqueri,horizonte es se proveniente de material de origem diferente.

Embora o argilomineral predominante seja a cau linita, esses solos apresentam altos teores de gibbsita e que associados aos altos valores de intemperismo médio $(5,0$ a 5,6$)$ tais solos se apresentam nitidamente como os mais intemnerizados da região (Quadro 1).

As variações mineralögicas em profundidade não são significativas nos latossolos MONIZ \& JACKSON(1967) e ESCOBAR et al., (1973), a excessão dos casos de recobrimento (unidade Piqueri, nuadro 1 ).

Os principais componentes da fração argila desses solos constam dos difratogramas (Figuras 24 a 26) e nos termogramas (Figuras 27 a 29 ) constam os minerais gibbsita e caulinita.

Na fração grosseira, nota-se a brusca diminui- 
ção de quartzo, seguida de um aumento de ortoclảsio (Qua dro 3) nos perfis da unidade Piqueri (evidência de recobrimento) e a diminuição gradativa do quartzo na unidade Tanque, em que não se encontrou evidência de recobrimento atê a profundidade estudada do solo. 


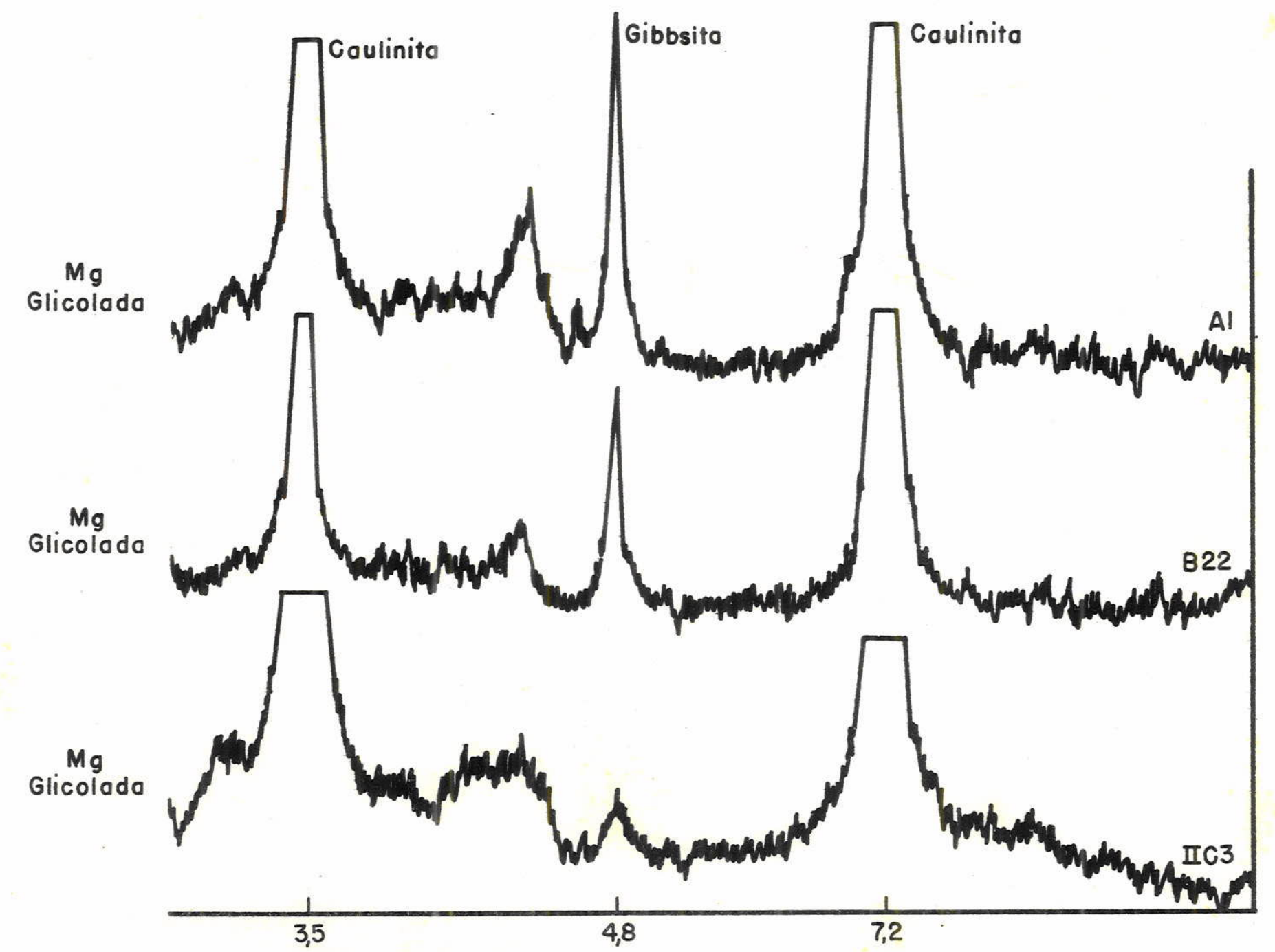

Figura 24 - Difratogramas da fração argila de amostras orientadas da unidade Piqueri, perfil 1051 


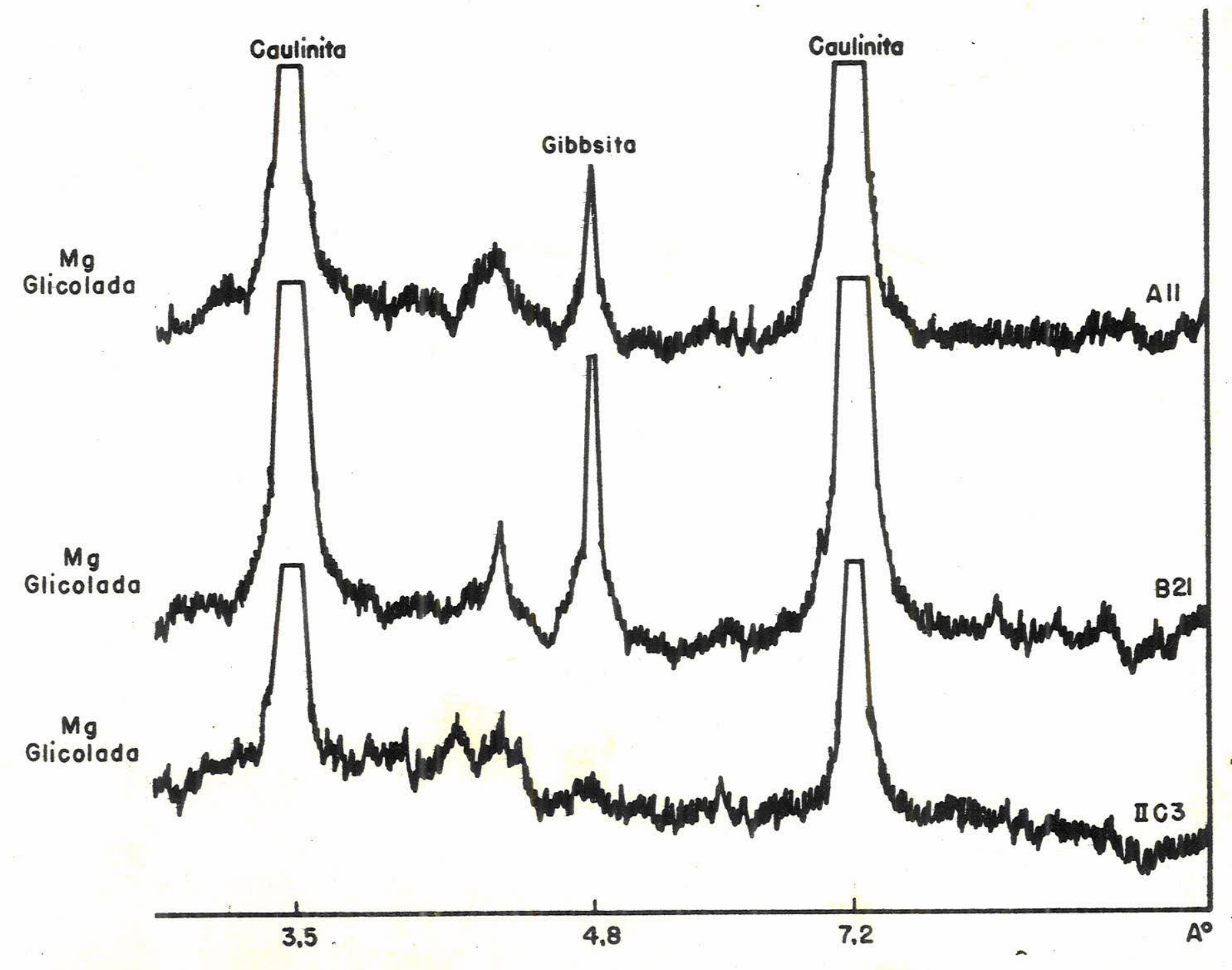

Figura 25 - Difratogramas da fração argila de amostras orientadas da unidade Piqueri, perfil 1031 


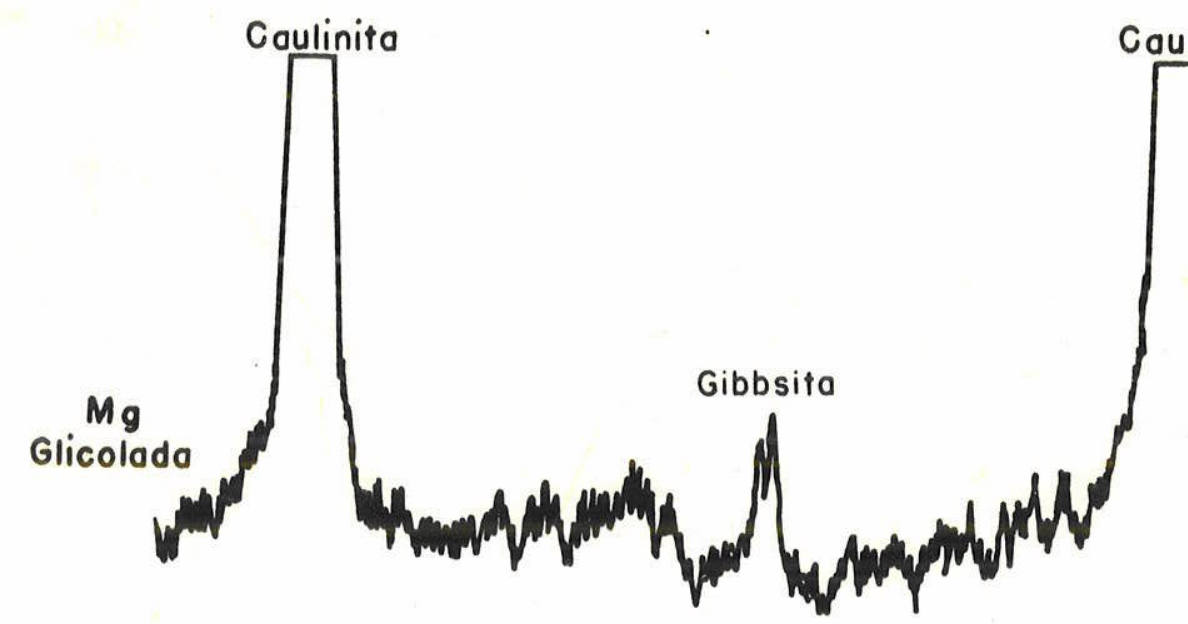

Caulinita
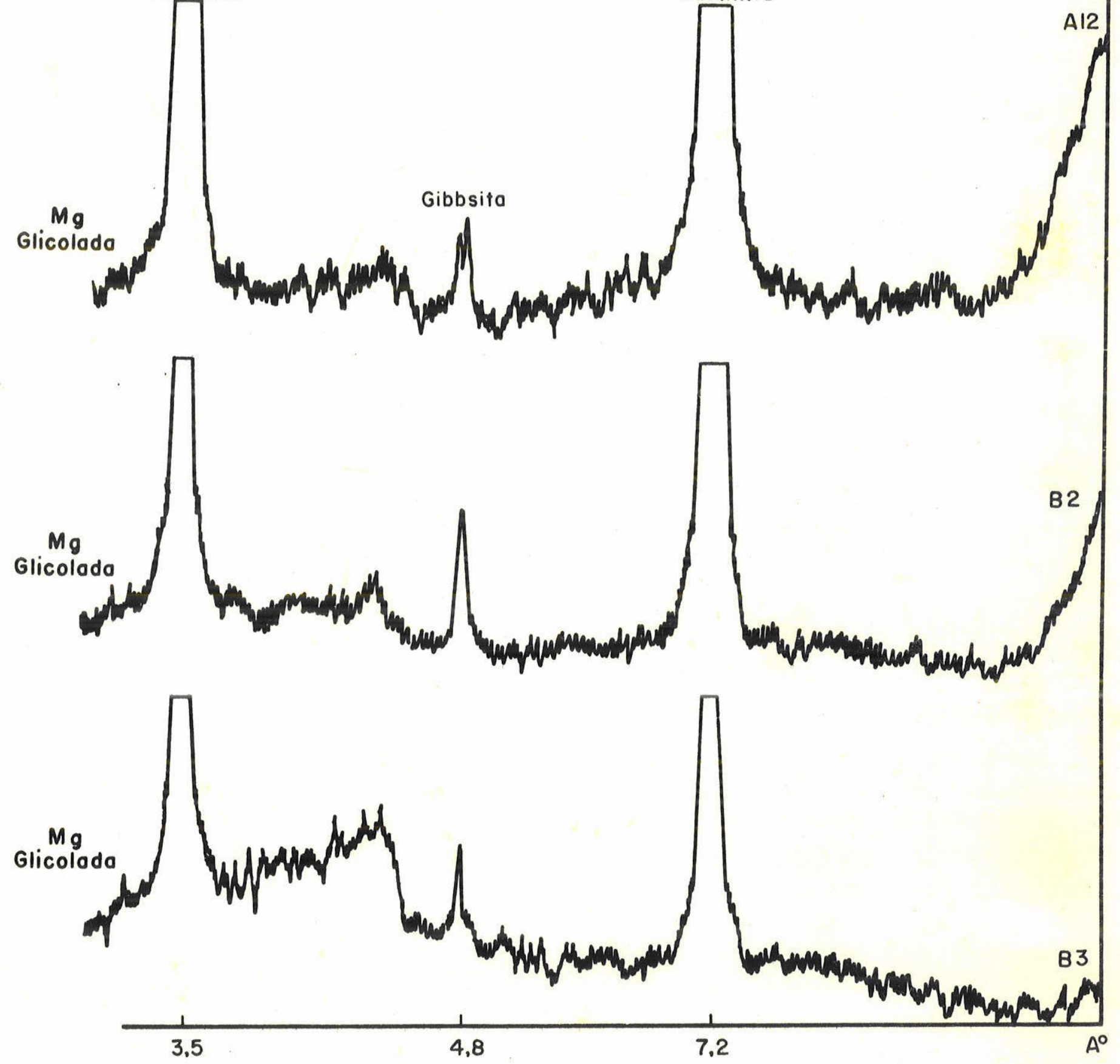

Figura 26 - Difratogramas da fração argila de amostras orientadas da unidade Tanque, perfil 1063 


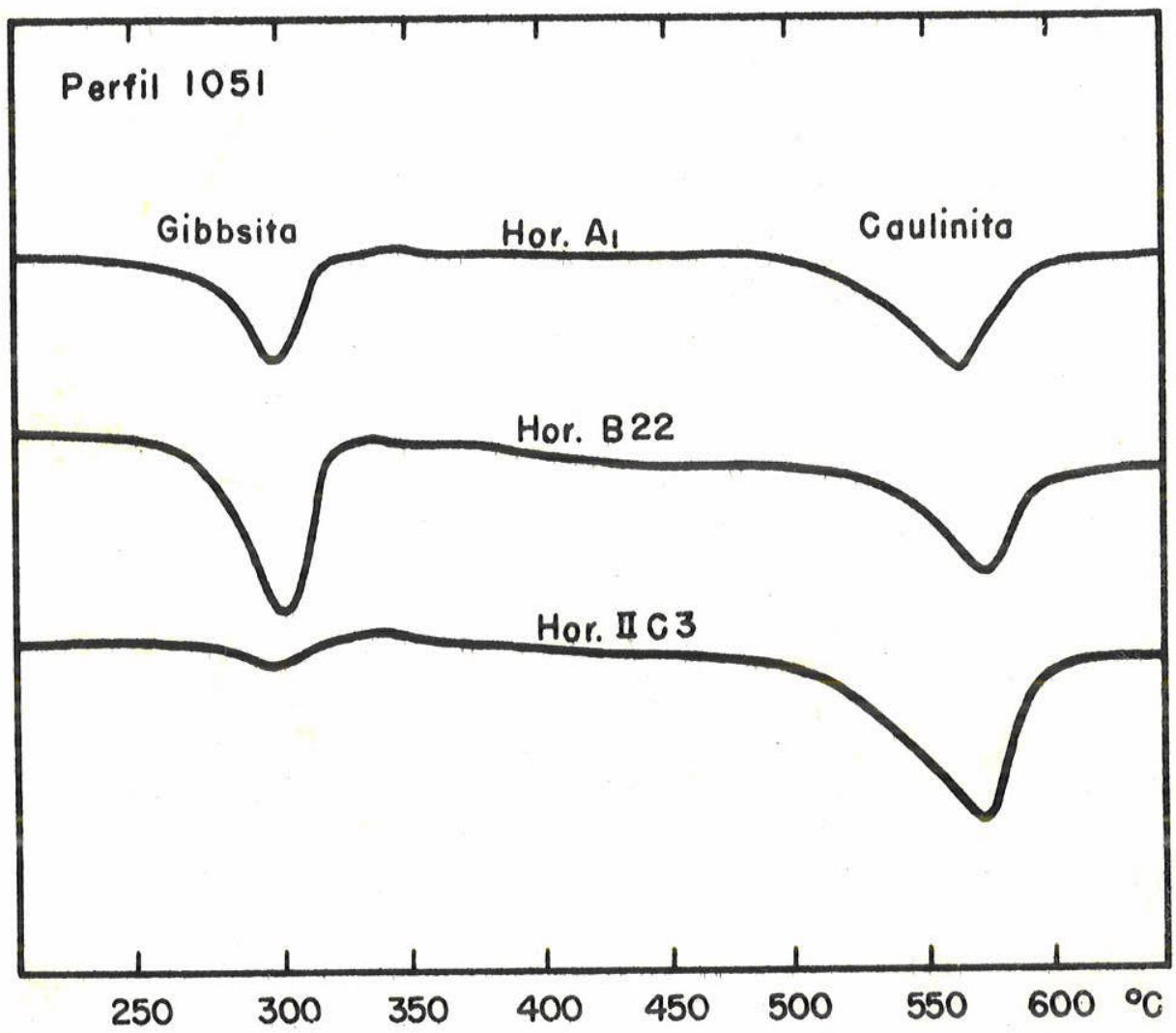

Figura 27 - Termogramas da fração argila da unidade piqueri, perfil 1051 


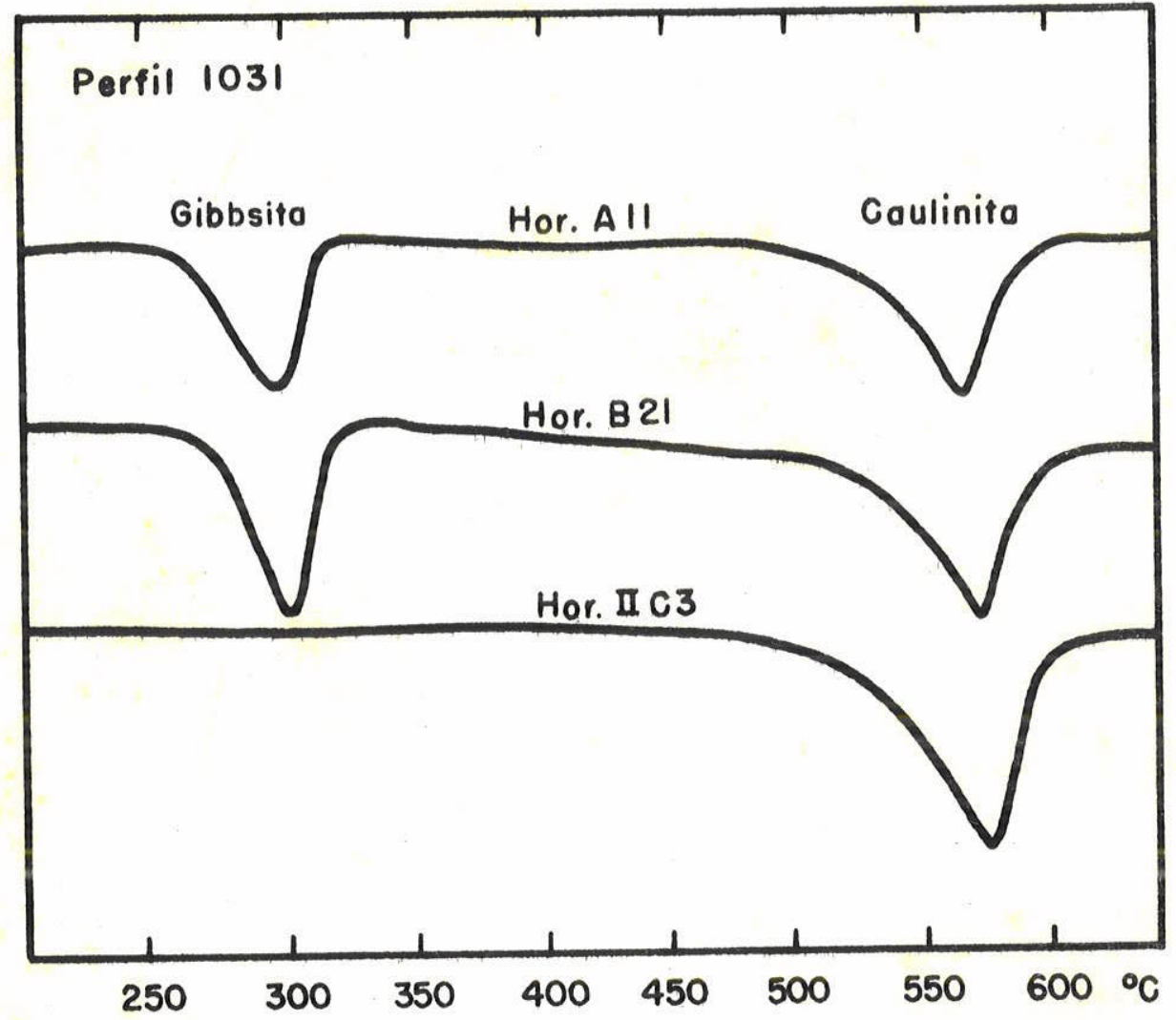

Figura 28 - Termogramas da fração argila da unidade Piqueri, perfil 1031 


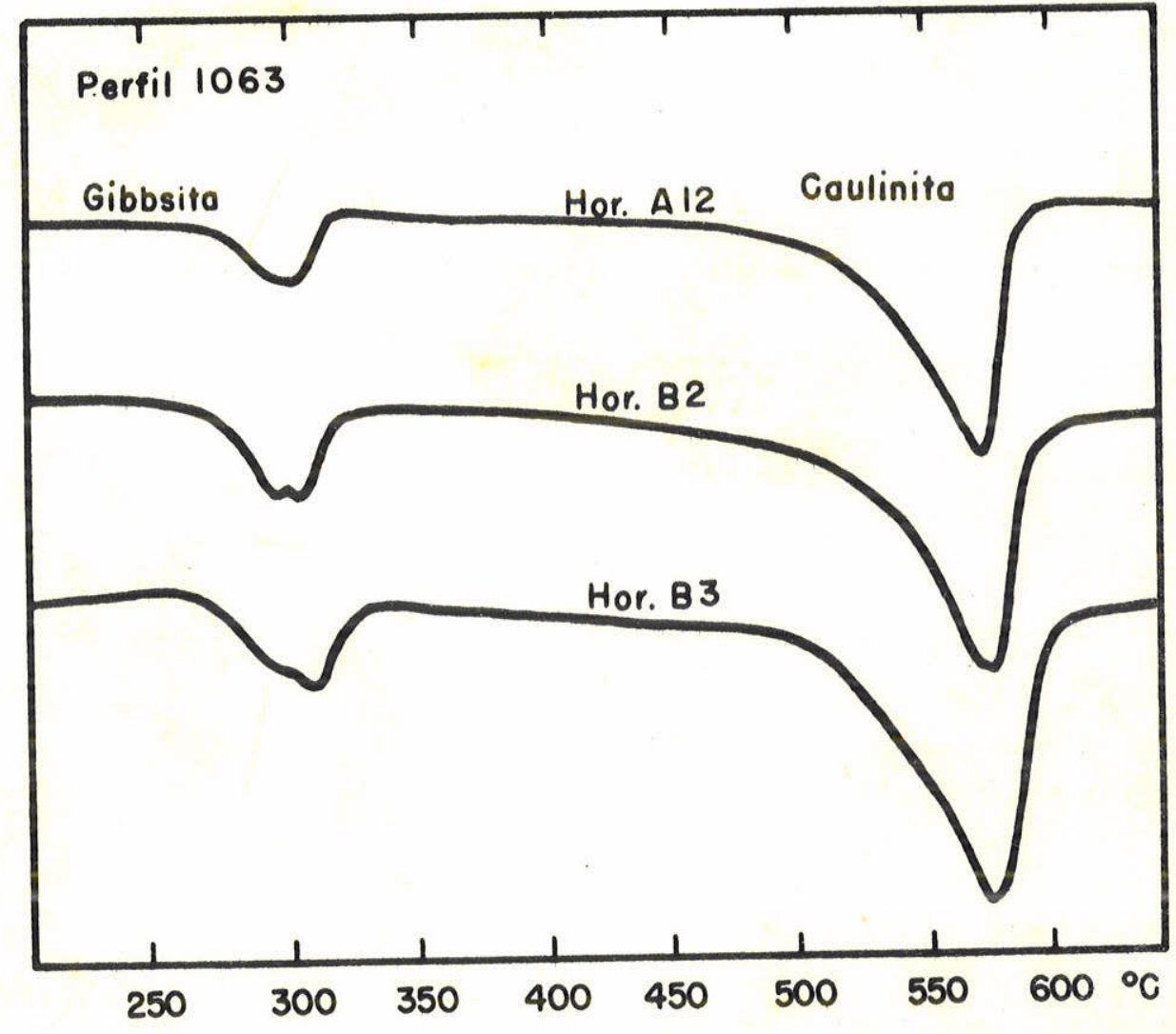

Figura 29 - Termogramas da fração argila da unidade Tanque 


\section{CONCLUSOES}

Nos trabalhos de mineralogia de solos brasileiros pouco desenvolvidos não se encontrou referência a teo res altos de gibbsita como foi verificado no perfil da unidade Itapetinga, que apresentou $30 \%$ desse mineral na sua fração argila. Valores altos são comumente encontrados em latossolos.

A caulinita foi o argilomineral dominante em to dos os perfis estudados havendo uma ligeira diminuição em superfície, compensado por um aumento de gibbsita. Em cer tos casos contudo esta relação foi mascarada pelo recobrí mento.

Algumas evidências de descontinuidade puderam ser comprovadas pela observação da variação dos minerais da fração areia, principalmente dos podzólicos. 
A existência de elevados teores de feldspatos nos horizontes superios dos solos da parte alta da topos sequência (embora sejam solos rasos) vem mostrar que tais solos possuem elevados teores em nutrientes a serem liberados gradativamente pelos processos de intemperismo.

O estudo mineralógico da fração argila dos solos da topossequência poude auxiliar na verificação de solos com recobrimento, como exemplo as unidades Rosâ.rio, Cachoeira e Piqueri. Nessas unidades, o aumento brus co de caulinita, acompanhado de brusco decréscimo de gib bsita nos horizontes abaixo do retrabalhamento, evidencia ou pelo menos é um dado a mais para se confirmar o recobrimento.

0 estudo da fração areia tambëm teve sua utili. dade na verificação do retrabalhamento. Poude-se verificar a variação brusca de quartzo e mica nos horizontes transportados das unidades Samambaia, Rosārio, Cachoeira, Caetetuba e Piqueri. Tal variação tambẻm ocorreu com ortoclâsio nas unidades Caetetuba e Piqueri, nos horizontes retrabalhados.

0 indice de intemperismo mêdio mostrou ser efi ciente para avaliação da evolução dos solos.

Os solos da parte alta da topossequência. são os menos intemperizados, com seus valores mêdios de intemperismo 2,6 a 3,0 (Quadro 1). Os solos da parte baixa são os mais desenvolvidos com valores de intemperismo mé 
dio 5,1 (valor mëdio entre 5,0 e 5,3 ) e 5,5 respectivamente.

Os solos da unidade Itapetinga foram enquadrados na familia oxidica, segundo Soil Survey Staff (1960), por pertencerem a classe Barrenta e tambëm em virtude da relação

$\left(\%\right.$ de $\mathrm{Fe}+\frac{\circ}{0}$ de gibbsita/ $\%$ de argila) ser maior que 0,2 .

Os solos da unidade Samambaia foram enquadrados na família silícica por pertencerem à classe Barrenta e apresentarem mais de $90 \%$ de quartzo na fração $0,02 \mathrm{~mm}$ $2 \mathrm{~mm}$.

Os solos das demais unidades foram enquadrados na familia caulinitica por pertencerem à classe Argilosa e apresentarem mais de $50 \%$ de caulinita na fração argila. 
Este trabalho é um estudo mineralógico de solos de uma topossequência do município de Atibaia, SP.

Foram selecionados onze perfis (totalizando trinta e cinco amostras de solos) pertencentes aos seguintes tipos: Litossolo substrato granito,Podzôlico com cascalho, Podzólico Vermelho Amarelo orto, Podzólico Ver melho Amarelo raso, Latossolo Vermelho Amarelo orto, Latossolo Verme1ho Amare1o Húmico e Latossolo Vermelho Ama relo fase rasa. Tais solos desenvolveram-se sobre granito, gnaisse e xisto, como tambëm sobre materiais oriundos de sedimentos modernos ou pedissedimentos.

Embora se tenha trabalho com solos de materiais de origem diferentes, qualitativamente não se notou diferenças mineralögicas acentuadas na fração argi1a, que apresentou a caulinita como mineral predominante. 
Essa afirmação também é vảlida para os minerais da fração areia, a excessão do plagiocläsio encontrado apenas nas unidades de solos pouco desenvolvidas ou sejam, unidades Itapetinga e Rio Acima. Isto se explica por se tra tarem de solos rasos.

Qualitativamente também não se notou diferenças mineralógicas entre solos dos tipos podzölico e latosso10, porém o que se poude observar é que nos podzólicos, as variações em profundidade foram mais acentuadas e nos latossolos (quando não foi verificado recobrimento) a varia ção mineralógica em profundidade foi muito pequena.

Sob o ponto de vista quantitativo poude-se notar que independente do material de origem e do tipo de solo estudado, a caulinita foi o mineral predominante da fração argila (teores entre 45 a $85^{\circ}$ ). Na fração areia, o mineral que alcançou teores mais elevados foi o quartzo (teores entre 21 e 99\%) a excessão da unidade Itapetinga, em que predominou o ortocläsio. 


$$
8 \text { - BIBLIOGRAFIA }
$$

ALEXIADES, C.A. \& M.L. JACKSON - 1965 - Quantitative de termination of vermiculite in soils - Proc.Soil Sci. Soc. Am. 29: 522-527

ALMEIDA, F.F.M. de - 1964 - Fundamentos geológicos do re levo paulista - In: Geologia do Estado de São Paulo IGG. Bo1. 41: pp 167-263

ANDRADE,S.S.; J.L.I. DEMATTE \& A.C.MONIZ - 1974 - Gênese de tres catenas de solos localizadas nos municípios de Piracicaba e Rio Claro, SP. In: Congresso Bras. de Ciência do Solo, 14. Santa Maria, 973. Anais. Santa Maria, Soc.Bras,de Ciência do Solo: pp $573-590$

BIDWELL, O.W. \& J.B.PAGE - 1950 - The effect of weathering on the clay mineral composition of soils in the Miami catena - Soil Sci.Soc. Am. Proc. 15: pp 314-318 BITTENCOURT, I - 1972 - Introdução à Geologia do Vale do Rio Atibaia, SP - Seminârio Geral apresentado ao Ins tituto de Geociências da USP - Mimiografado, $10 \mathrm{n}$. 
BLOSS, F.D. - 1961 - An introduction to the methods of Optical Crystallography - Southern I11inois University, E.U.A., 294 p.

BRINDLEY, G.W. - 1955 - Identification of clay minerals by $\mathrm{X}$-ray diffraction analysis. In: Nat. Conf. on Clays and Clay Tecnology, $1^{\text {th }}$. Proceedings.San Fran cisco, Dep.of Nat. Resources, pp 119-129

BUSHNELL, T.M. - 1942 - Some aspects of the soils catena concept. - Soil Sci. Soc. Am. Proc.7: pp 466-476

CARVALHO, A. - 1971 - Study of Terra Roxa Estruturada and Latossolo Roxo on a Topographic sequence in São Paulo State, Brazil - Tese apresentada na University Newcastle Upon Tyne, para obtenção do grau de M.Sc., $93 \mathrm{p}$

CARVALHO, A. \& C.L. ROTTA - 1974 - Estudos das formações superficiais do município de Atibaia, SP - Bol. Pau lista de Geografia 49: pp 5-22

CARVALHO, A.; I.F. LERSCH; J.B.OLIVEIRA; J.M.A.S. VALAD $\underline{\Lambda}$ RES \& C.L.ROTTA - 1972 - Levantamento pedolögico se midetalhado do município de Atibaia, SP - Bragantia, no prelo.

CATE Jr., R.B. - 1960 - Studies on gibbsite acumulations in soils - Tese de M.Sc. - Graduate Faculty of North Carolina State College - Raleigh

CORDANI, U.G. G I. BITTENCOURT - 1967 - Determinações de idade potássio-argônio em rochas do Grupo Açungui. In: Congresso Brasileiro de Geologia, XXI, Curitiba, 1967. Anais. São Paulo, Soc.Bras.de Geologia: pp 218-233 
DANA, J.D. \& C.S.HURLBUT - 1969 - Manual de Mineralogia. R.R.Franco, tradução - Editora da Universidade de São Paulo, $642 \mathrm{p}$

DEFONTAINES, P. - 1935 - Regiões e paisagens do Estado de São Paulo - Primeiro esbôço da divisão Regional. Geografia, São Paulo, 1(2): pp 117-160

DE MARTONE, E. - 1943 - Problemas morfológicos do Brasil Tropical Atlântico - Rev.Pras.Geografia 5(4): pp 523-550

DIXON, J.B. - 1966 - Quantitative analysis of kaolinite and gibbsite in soils by differential thermal and selective dissolution methods. $14^{\text {th }}$. In: Nat. conf. Clays and Clay Minera1s, $14^{\text {th }}$. Proceedings. New York, Pergamon Press, 26: pp 83-89

DUDAS, J.J. ६ D.M.E.HARWARD - 1971 - Effect on dissolution treatments on standard and soil clays - Soil Sci. Soc. Am. Proc. 35: pp 134-140 ESCOBAR, E.H.; J.L.I.DEMATTE \& A.C.MONIZ - 1973 - Gênese e classificação de alguns solos da bacia do Ribeirão Tijuco Preto, município de Rio das Pedras, SP. I - Análise mineralógica. Bragantia 32: pp 93-116

EUA - Soil Taxonomy - 1970 - (Selected chapters from the unedited text). Washington

FIELDS, M. \& K.W. PERROTT - 1966 - The Nature of allopha ne in soils. Part 3 - Rapid Field and Laboratory Test for Allophane - New Zealand Journal of Science 9: pp 623-629

FRANSMEIER, D.P.; E.J. PEDERSEN; T.J. LONGWELL; J.G.BYRNE \& C.K.LOSHE - 1969 - Properties of some soils in Cumberland Plateau of related to slope aspect and position - Soil Sci.Soc.Am.Proc.33: pp 755-761 
GIRARDI,V.A.V. \& A.J.MELFI - 1963 - Mineralogia dos solos da Sẻrie Taquaral na Estação Experimental Teodureto de Camargo - Bragantia, 22 (13):pp 139-148

GREENE, H. - 1947 - Soil formation and water movement in the tropics - Soil and Fertilizers, 10(3): pp 253-256

GRIFFITH, G. - 1952 - Catena - Soil and Fertilizers, 15 (3): pp 169-170

HASEMAN, J.F. \& C.E.MARSHALL - 1945 - The use of heary Minerals in studies of the origen and development of soils.University of Missouri - Agricultural expe riment station - Research Bulletin, 387, $75 \mathrm{p}$

HASHIMOTO, I. \& M.L.JACKSON - 1960 - Rapid dissolution of allophane and kaolinite-halloysite after dehydration - Clay and Clay Minerals - In: Nat.conf. $14^{\text {th }}$. Proceedings. New York, Pergamon Press, 5: pp 102-113

HEINRICH, K.W'm. - 1965 - Microscopic identification of minerals - McGraw-Hill Book Co., New York, $414 \mathrm{p}$ HSU, P.H. - 1963 - Effect of initial pH, phosphats and silicates in determination of aluminun with aluminun - Soi1 Sci. 96: pp 230-238

JACKSON, M.L. - 1964 - Prentice Hael Inc., Englewood cli fts. N.J. $498 \mathrm{p}$

JACKSON, M.L. - 1969 - Soil chemical analysis - Advanced course - Univ.of Wisconsin - Madison, Wis., $991 \mathrm{p}$ (mimiografado)

JACKSON, M.L.; B.A.TYLER; A.L.WILLIS; G.A.BOURBEAU · $\oint_{1}$ R.P.PENNINGTON - 1948 - Weathering sequence of clay size minerals in soils and sediments: I - Fundamental generalization. Journ. of Phis.and Colloid Chemistry, 52: nn 1237-1260 
JACKSON, M.L. \& G.D.SHERMAN - 1953 - Chemical weathering of minerals in soils - Advanced Agmen. 5:pp 219-318 JOHNSON, L.J. \& C.JEFFRIES - 1957 - The effect of draina ge on the weathering of the clay minerals in the Allenwood catena of Pensylvania - Soil Sci. Soc.Am. Proc. 21(5): pp 539-552

KRUMBEIN, W.C. E F.J.PETTIJOHN - 1938 - Manual of sedimentary petrographi - The Century Earth Science series. New York, $549 \mathrm{p}$

LEINZ, V. \& J.E.S. CAMPOS - 1968 - Guia para determinação de Minerais $-4^{\mathrm{a}}$ ed., São Paulo - Editora Nacional e Editora da USP, $140 \mathrm{p}$

LEPSCH, I.F. - 1973 - Genesis, Morphology and classifica tion of soils in an oxisol-untisol toposequence in São Paulo State, Rrazil - Raleigh, M.Sc. - Thesis North Caroline State Iniversity at Raleigh, $88 \mathrm{p}$ MARTIN, R.T. \& Y.B.RUSSELL - 1953 - Clav minerals of four southern New York soils - Soil Sci., 74: pp 267-279

MCCRAKEN, R.J.; E.J.PEDERSEN; L.E.AULL; C.I. RICH \& T.C. PEELE - 1971 - Soils of the Hayesville, Cecil and Pacolet series in the southern Anpalachian and Pied mont regions of the United States. Southern coopera tive series - Bulletin $n^{\circ}$ 157, April. North Caroline State University of Raleigh - Soil Conservation Service, U.S.Dento. of Agriculture

MEHRA, O.P. \& M.L.JACKSON - 1969 - Remoral of free iron oxides from soil or clay hy sodium dithionite-citra te-bicarbonate method. In: M.L.Jackson - Soil Chemi cal analysis-advanced course. Univ of Wisconsin.Madison, Wis., 991 p. (Mimiografado) 
MELFI, A.J.; V.A.V.GIRARDI \& A.C.MONIZ - 1966 - Mineralo gia dos solos da Estação Experimental "Theodureto de Camargo" - Bragantia 25: pp 9-30

MOMBEIG, P. - 1954 - Os problemas da divisão regional do Estado de São Paulo - In: Aspectos Geogräficos da Terra Bandeirante - Rio de Janeiro, IBGE, pp 181 207

MONIZ, A.C. \& A.CARVALHO - 1973 - Sequência de evolução de solos derivados do arenito Bauru e de rochas bäsicas da região Noroeste do Estado de São Paulo Bragantia 32: pp 309-335

MONIZ, A.C. E M.L.JACKSON - 1967 - Quantitative Mineralo gical analysis of Brazilian soils derived from basic rocks and slate - Univ of Wisconsin, Madison, Wis. - Soil Sci. Report 212

PENALVA, F. - 1971 - Sedimentos neocenozóicos nos vales dos rios Jundiaí, Atibaia e Jaguari - Bol.Paul. de Geogr. 46: pp 107-138

PORTAS, C.A.M. \& A.F.A.S.FURTADO - 1964 - Reserva Mineral e minerais da areia de alguns solos da Cela (Aㅡ gola). Estudos, ensaios e documentos $\mathrm{n}^{\circ} 115$ - Junta de Investigações do U1tramar. Lisboa

ROGERS, A.F. \& P.F.KERN - 1942 - Optical Mineralogy McGraw-Hi11 Book Co., Inc. - New York, 390 p

RUHE, R,V - 1956 - Geomorphic Surfaces and the nature of soils - Soil Sci. 82: pp 441-455

RUHE, R.V. - 1960 - Elements of the soil landscape. In: Trans. $7^{\text {th }}$ International Congress of Soil Sci., Madi son, U.S.A., 4: pp 165-169

RUHE, R.V. - 1969 - Quaternary Landscapes in Iowa - Iowa State University, U.S.A., $255 \mathrm{p}$ 
SERVIÇO NACIONAL DE' PESOUUSAS AGRONÔMICAS - 1960 - Comis são de Solos - Levantamento de reconhecimento dos solos do Estado de São Paulo - Rio de Janeiro, Minis tërio da Agricultura - Boletim 12: $634 \mathrm{p}$

SLAVIN, W. - 1968 - Atomic Absorption Spectroscopy - Che mical Analysis, 25: - Interscience Publishers, New York, $307 \mathrm{p}$

SOIL SURVEY STAFF - 1960 - Soil classification. A compre hensive system $7^{\text {th }}$ aproximation - Washington, $265 \bar{p}$ TEDROW, J.C.F - 1951 - Influence of topography and position on classification of soils haring impeded drai nage - Soil Sci. 71: pp 429-437

WATSON, I. P. - 1965 - Soil Catenas - Soils and Fertilizers XXVIII (4): pp 307-310

WOHLERS,A.; S.MEZZALIRA \& J.SETZER - 1954 - Geologia da Folha de Jundiai - IGG, vol. 11 e 12 


\section{9 - AGRADECIMENTOS}

Queremos manifestar nossos agradecimentos a todas as pessoas e Instituições que direta ou indiretamente deram sua contribuição para sua realização.

No Dr. Antônio Carlos Moniz, a quem devemos parte da nossa formação cientifica, pois jamais poupou esforços em apoiar-nos nos trabalhos de laboratörio, na indicação da bibliografia especializada e no aprendizado da teoria e prática de raios-X e anālise térmica diferen cial.

Ao Dr. Umberto G. Cordani pela orientação, tán to nos cursos de pós-graduação e exame de qualificação como para a realização deste trabalho, pois como orientador sempre manifestou a melhor boa vontade. 
Ao Dr. Adolpho José Melfi e Dr. Bernardo van Raij pelas críticas e sugestões.

Aos colegas da Seção de Pedologia do Instituto Agronômico de Campinas.

A Dona Nair de Campos Louzada e ao Sr. Josë Pon chirolli pela composição datilogräfica e ao Sr. Jayme A 1 ves da Silva pela impressão.

Ao Departamento de Desenho Têcnico do Instituto Agronômico, especialmente ao Sr. Neme, pelos desenhos.

$A$ direção do Instituto Agronômico de Campinas pelo uso dos laboratórios, aparelhos e materiais.

Finalmente, agradecemos ao Conselho Nacional de Pesquisas (CNPq) pelo auxílio financeiro (bolsa de complementação salarial) e pelos aparelhos (microscópio po1 arizador e rajos $-X$ ). 